\title{
«EN CASA [, CAMA] Y COMPAÑIIA». YACER A LOMOS DEL XVIII EN LOS HOGARES ECLESIÁSTICOS BURGALESES
}

\author{
POR \\ Francisco J. SANZ DE LA HiguerA* \\ IES «Torreblanca» (Sevilla)
}

\begin{abstract}
RESUMEN
Las conductas sexuales de varios clérigos en el Burgos de mediados del Setecientos ¿son un síntoma generalizado o una mera excepción? La mayoría de los clérigos burgaleses residían en hogares ensanchados por razones laborales, merced a la presencia de una o varias criadas. La tentación estaba al otro lado de las puertas de sus dormitorios. Al fallecer, un número notable de últimas voluntades de los presbíteros burgaleses ordenaba la entrega a su servicio doméstico femenino de «una cama completa». ¿Existía alguna causa inconfesable?
\end{abstract}

PALABRAS ClAVE: Clérigo, Sexualidad, Embarazo, Hogar, Cama.

\begin{abstract}
The sexual behaviour of several priests in Burgos in the middle of the 18th century, is it a widespread sign or just an exception? Most the clergymen from Burgos lived in household enlarged for working reasons, thanks to the presence of one or several maids. The temptation was at the other side of their bedroom doors. When they died, an important number of the last wills of the clergymen in Burgos presented «una cama completa» to their female servants. Was there a secret reason?
\end{abstract}

KEY WORDS: Clergymen, Sexuality, Pregnancy, Household, Bed.

\footnotetext{
* A las traductoras de los «Abstract» de los artículos que se me han publicado, dos magníficas amigas y compañeras en los apasionantes pero también sufridos quehaceres de la docencia en las enseñanzas medias, Pilar REDONDO y Guadalupe FERNÁNDEZ, profesoras de inglés en Torreblanca.
} 
Eran, sin duda, una excepción a la regla. Empero, la regla quedaba en entredicho ó suspendida de manera radical a partir de ese exacto momento. El escándalo estaba servido. La carencia de menstruación, el embarazo y, en ocasiones -no siempre-, el alumbramiento de una criatura fue lo que, íntimamente primero y abiertamente después, les delató a ambos, al clérigo y a la sirvienta, ante sus convecinos. La mayoría de los eclesiásticos del XVIII cumplía, de grado o por fuerza, con el celibato, y algunos hasta soportaban también la pobreza ${ }^{1}$. Sólo una minoría traspasó el umbral de las sábanas de sus criadas, o de la mujer en general. Las consecuencias resultaban siempre voluminosamente embarazosas. Son, en el inmenso cúmulo de la documentación manejada, muy raros, casi insólitos, los casos en que hallamos constatación escrita y verídica de que algo ocurrió entre las paredes de las viviendas que albergaban a esas personas. Eran parejas de hecho, arrojadas, en ocasiones, por la soledad y la convivencia bajo el mismo techo, al deseo carnal y al carnal disfrute ${ }^{2}$. ¿Existe vinculación con lo económico, con el rango, con el estatus...?

\section{ANÁLISIS DE LAS FUENTES DOCUMENTALES Y BIBLIOGRAFÍA}

Las reflexiones que se vierten en estas páginas son el fruto de un rastreo sistemático y exhaustivo en el inmenso océano de los protocolos notariales, en las recias actas capitulares de la Catedral de Burgos y en los centenares de folios que conforman los libros del Catastro de Ensenada ${ }^{3}$. Los tres episodios constituyen, en sí mismos, documentos modélicos en los que se constatan fenómenos fuera de la común. Empero, aunque se trata de hechos aislados, van a inducir a

\footnotetext{
${ }^{1}$ Finalmente llegaremos con el profesor Bravo Lozano a concluir que «La imagen de un clero «trasgresor/pecador» no parece muy consistente; muy al contrario, se impone la idea de que en conjunto estamos ante un grupo social, los eclesiásticos, que aceptaban satisfactoriamente sus obligaciones, tanto pastorales como de comportamiento, incluso en el campo de la sexualidad». J. BRAVo LoZANO: Familia busca vivienda. Madrid, 1670-1700. Madrid, 1992, pp. 106. Empero, una pequeña muestra del porcentaje de incumplimientos a la castidad por parte del clero, generalmente amancebamientos - datos extraídos de los procesos contra eclesiásticos- produce un escalofrío no exento de polémica y escándalo. En Cuenca, entre el 10 y el 19\%. En Córdoba, alrededor del 14\%. En Cantabria, entre el 15 y el 20\%. En Sevilla, entorno al 21\%. En Lugo, aproximadamente el 25\%, ó en Toledo, el $30,6 \%$. Estos porcentajes proceden de las publicaciones que serán reseñadas en la anotación dedicada a la bibliografía.

${ }^{2}$ No hemos de obviar, en última instancia, la existencia de una posible atracción física entre la criada ó el ama y el clérigo, un enamoramiento incendiario - aunque fuera momentáneo-, u otras causas concomitantes y coadyuvantes, como la violencia de género con ribetes socio-laborales.

${ }^{3}$ La documentación histórica consultada se halla custodiada en el Archivo Histórico Provincial de Burgos. Protocolos Notariales -en lo sucesivo AHPB. PN-, el Archivo Capitular de la Catedral de Burgos — en adelante ACCB - y el Archivo de la Diputación Provincial de Burgos - ADPB —, Catastro de Ensenada. Se citarán oportunamente en cada momento los legajos y libros concretos de donde procede la información utilizada.
}

Hispania Sacra, LVIII

118, julio-diciembre 2006, 545-577, ISSN: 0018-215-X 
un sondeo detenido en las maneras de vivir - los hogares como contenido y como continente ${ }^{4}$ - y en las maneras de comportarse del clero burgalés de mediados del Setecientos. Los casos que se traen a colación ¿fueron ocurrencias absolutamente extraordinarias? ¿Eran la punta visible de un iceberg sociológico de magnitud notable? Es evidente que - parafraseo al magnífico profesor y excelente amigo Francisco Núñez Roldán - tres «episodios no hacen historia, (pero) por la ejemplaridad que suponen «son auténticamente relevantes ${ }^{5}$.

Argüir que con únicamente tres documentos se puede construir un imaginarium histórico puede parecer sencillamente ridículo. Tal vez, incluso, una estridencia abominable. Los trabajos de Candau Chacón ${ }^{6}$, Dubert García ${ }^{7}$ y Barreiro Mallón ${ }^{8}$ - por citar tres de los más representativos- dejan en evidencia, por el volumen de pleitos que manejan, el escaso número de hechos aquí manejado. Dado que mi intención no es otra que sugerir la existencia de comportamientos extravagantes protagonizados, de una manera u otra, por algunos eclesiásticos en el seno de una modesta ciudad de provincias - localidad venida a menos durante el XVII y el XVIII desde un XVI efervescente y glorioso-, el leiv motiv está presumiblemente conseguido.

Los documentos recopilados proceden de tres fuentes distintas. En primera instancia, un protocolo notarial titulado «Reconozimiento de Una Criatura Dn fran $^{c o}$ de Agustina Cariga (...) Presbítero Benefiziado en la Parrochial del lugar de Carasa Junta de boto merindad de trasmiera» (1731) ${ }^{9}$. En segundo término, una carta de una dignidad y canónigo de la catedral al arzobispo (1765),

4 F. SANZ DE LA HIGUERA: «Familia, hogar y vivienda en Burgos a mediados del siglo XVIII. Entre cuatro paredes, compartiendo armarios, camas, mesas y manteles», Investigaciones Históricas, Valladolid, 22 (2002), pp. 165-211.

5 F. NùÑEz RoldÁn: La vida cotidiana en la Sevilla del Siglo de Oro, Sevilla, 2004, pp. 131.

6 M. L. CANDAU CHACón: Los delitos y las penas en el mundo eclesiástico sevillano del XVIII, Sevilla, 1993 y La carrera eclesiástica en el siglo XVIII, Sevilla, 1993. En ellas se detallan sus muchos artículos publicados, de evidente interés también para el seguimiento de los asuntos aquí propuestos.

7 I. DuBert GARCíA: «Alma de curas y cura de almas. Moral y comportamientos eclesiásticos en la Galicia interior durante el Antiguo Régimen (1600-1830)», Las religiones en la historia de Galicia, Santiago de Compostela, 1996, «Los comportamientos familiares del clero urbano en Galicia: el ejemplo de Santiago de Compostela en el siglo XVIII», Compostellanum, 31 (1986), Santiago de Compostela, pp. 443-455, «Los comportamientos sexuales premaritales en la sociedad gallega del Antiguo Régimen», Stvdia Historica, IX (1991), Salamanca, pp. 117-142 (en especial, p. 139) e Historia de la familia en Galicia durante la época moderna, 1550-1830. (Estructura, Modelos hereditarios y Conflictividad), La Coruña, 1992. Se traen a colación los títulos más representativos, sin ánimo exhaustivo.

8 B. BARReiro Mallón: «El clero de la diócesis de Santiago: estructura y comportamientos (siglos XVI-XIX», Compostellanum, 33 (1988), Santiago de Compostela, pp. 469-507, «Sínodos, Patronos y Expedientes. Tres indicadores de la religiosidad en el N.O. de la Península», L. C. ÁlVAREZ SANTALÓ (dir.), La Religiosidad Popular, volumen 2, Sevilla, 1989, pp. 72-95, «Las clases urbanas de Santiago en el siglo XVIII: Definición de un estilo de vida y de pensamiento», AA.VV., Historia social de Galicia en las fuentes y protocolos, Santiago de Compostela, 1981, pp. 449-493, ídem.

9 AHPB. PN. Legajo 7001 (1731), folio 459. 
documento custodiado en el Archivo Capitular. Su contenido es realmente explosivo $^{10}$. En esas instalaciones están celosamente recogidas también las Actas de la Mesa Capitular redactadas a instancias del deán y Cabildo de la susodicha Catedral. Los extraños, y censurados, comportamientos de un canónigo generaron indignación y un enorme revuelo en el seno de la más encumbrada institución eclesial de la ciudad (1750) ${ }^{11}$.

La bibliografía sobre tan espinoso tema no es aún muy densa pero aquella a la que hemos tenido acceso resulta rigurosa y de rotunda calidad y exquisitez. Descuellan los ya citados de Candaú Chacón, Dubert García y Barreiro Mallón, investigadores a los que es imprescindible añadir las contribuciones de Gutton, Álvarez Santaló, Saez, Bravo Lozano, Morgado García, Testón Núñez y Santillana Pérez, Cobos Ruiz de Adana, Sánchez González, Rodríguez Sánchez, Pueyo Colomina y Fonseca Montes ${ }^{12}$.

10 ACCB. Volumen 55, P2, 6 de julio de 1765, folio 128.

11 ACCB. Actas capitulares. Cabildo del 17 de agosto de 1750, folio 168.

12 J. P. Gutton: Domestiques et serviteurs dans la France de l'ancien régime, París, 1981, pp. 169-213. L. C. ÁlVAREz SANTALó: ""Vivir como un cura". Algunas precisiones cuantitativas respecto al imaginario social sobre el clero en el siglo XVIII», F. J. ARANDA PÉREZ (coord.): Sociedad y élites eclesiásticas en la España Moderna, Cuenca, 2000, pp. 101-147, y L. C. Álvarez SANTAló y A. GarcíABAQUERO GONZÁlEZ: «Riqueza y pobreza del clero secular en la Sevilla del Antiguo Régimen (17001834)», Trocadero, 8-9 (1998), Cádiz, pp. 11-47. R. SÁEZ: «La transgression de l'interdit amoureaux: le prêtre, la femme et l'enfant dans l'archevêché de Tolède (1565-1620)», A. REDONDo (dir.), Amours légitimes, amours illégitimes en Espagne (XVI $-X V I I^{e}$ siècles), París, 1985, pp. 93-100. J. BRAVo LoZANO: Familia busca vivienda,..., Madrid, 1992, pp. 95-112 y «Cura rico/cura pobre. Notas sobre las rentas eclesiásticas en el Madrid de fines del siglo XVII», E. MArtínEZ RuIZ y V. SuÁrez Grimón (eds.), Iglesia y sociedad en el Antiguo Régimen. Volumen 1, Las Palmas de Gran Canaria, 1994, pp. 129-139. A. Morgado García: Ser clérigo en la España del Antiguo Régimen, Cádiz, 2000, en especial las pp. 153-172, «Vida de canónigo. Percepción, origen y status del alto clero durante el Antiguo Régimen», F. J. Aranda PÉrez (coord.), Op. Cit., Cuenca, 2000, p. 77-99, y «El alto clero gaditano durante el Antiguo Régimen», Stvdia Historica, 16 (1997), Salamanca, pp. 223-255. I. TESTón NúÑEZ e I. SANTILLANA PÉREZ: «El clero cacereño en el siglo XVII. Comportamientos y mentalidades», Norba, 4 (1983), Cáceres y «El clero cacereño durante los siglos XVI al XVIII: comportamiento y mentalidad», Actas de las II Jornadas de Metodología Didáctica de la Historia. Historia Moderna, 1983, pp. 463-472. J. CoBos RuIZ DE AdANA: El clero en el siglo XVIII. Estudio de una visita secreta a la ciudad de Córdoba, Córdoba, 1978. R. SÁNCHEZ GonZÁlEZ: «El clero rural del arzobispado de Toledo en el Seiscientos: distribución, formación y conducta», Hispania Sacra, 46 (1994), Madrid, pp. 427-447, «El clero secular en los territorios de Órdenes: vita et moribus y tensiones con la Dignidad arzobispal», J. LóPEZ-SALAZAR PÉREZ (coord.): Las órdenes militares en la Península Ibérica, volumen II, Edad Moderna, Cuenca, 2000, pp. 2149-2177, y «Señorío y justicia en los Montes de Toledo: las causas de amancebamiento en la Edad Moderna», F. J. ArAndA PÉrez: Op. Cit., 2004, pp. 1285-1293. A. RodríGuez SÁNCHEZ: Hacerse nadie. Sometimientos, sexo y silencio en la España del siglo XVI, Lérida, 1998, y «Mal envuelto, mal lavado y con el ombligo mal cortado», Historia 16, 189, 1992, pp. 42-52. M. P. PUEYO Colomina: Iglesia y sociedad zaragozanas a mediados del siglo XVIII, Zaragoza, 1991, y J. FonSECA MonTEs: El clero en Cantabria en la Edad Moderna, Santander, 1996. Además son esenciales a este respecto, como contexto global, las siempre brillantes reflexiones del entrañable profesor Teófanes EgIDo LópeZ y las obras de M. T. BENITO AgUADO: La sociedad vitoriana en el siglo XVIII: el clero, es-

Hispania Sacra, LVIII

118, julio-diciembre 2006, 545-577, ISSN: 0018-215-X 
La compilación completa y el análisis exhaustivo de los memoriales del Catastro de Ensenada y de los gruesos legajos de los protocolos notariales de la ciudad de Burgos nos permiten auscultar, de una forma global, su vida cotidiana - dimensiones y tamaños de los hogares, niveles de renta y fortuna, estructura socio-profesional,...- y algunas de las facetas más significativas de sus mentalidades y comportamientos ante la muerte. La yuxtaposición de ambas fuentes documentales genera una visión estereoscópica de los quehaceres de la población burgalesa y de cada un a de sus categorías profesionales.

\section{Hogares eClesiásticos en Burgos. Bajo el mismo techo: LA TENTACIÓN CERCANA}

El clero secular burgalés se encontraba agrupado en 190 hogares, en el seno de los cuales eran albergadas 694 personas ${ }^{13}$. Ello supone el 6,5\% de las unidades de residencia y el $6 \%$ de los habitantes de la ciudad. La inmensa mayoría de ellos, el 83,7\%, disponía de servicio doméstico, personas que, de promedio, representan el 37,2\% de sus componentes. Su vida cotidiana no discurría, en general, por los derroteros de la estrechez, ni física ni económica. Al contrario, se desenvolvían en el seno de unos parámetros marcados por la comodidad y el confort. Desde cualquiera de las perspectivas que utilicemos en los análisis y con las obvias diferencias derivadas de sus rangos — véase cuadro I-, sabemos que disponían de bastantes metros cuadrados de suelos útiles para la convivencia —en corresidencia—, un más que substancioso nivel de rentas y prácticamente ninguna fatiga en el obligado cumplimiento del cansado mandato divino «ganarás el pan con el sudor de tu frente». Hacían - y ellos lo sabían y lo cultivaban con esmero y con celo- vida de arzobispo, canónigo, beneficiado ó capellán, respectivamente, en función de su estatus y nivel de fortuna. Tenían

pectador y protagonista, Bilbao, 2000, O. REY CASTELAO: «El clero urbano compostelano a fines del siglo XVII: Mentalidades y hábitos culturales», AA.VV.: Historia social de Galicia..., 1981, pp. 495519, y R. LóPEZ LÓPEZ: «Aproximación al clero urbano ovetense (1751-1790)», Cuadernos de Investigación Histórica, 11 (1989), Madrid, pp. 111-129, como ejemplos puntuales.

13 Otros hogares de la ciudad, más colectivos y numerosos, eran la residencia del Arzobispo (1744) — con 27 individuos - y los conventos, monasterios y colegios religiosos. Se trata, a mi entender, de hogares sin estructura familiar, TIPO 2. Los conventos y monasterios masculinos eran 12. Albergaban a 541 personas, de las cuales $111(20,5 \%)$ eran servidumbre. El promedio era $401 / 2$ religiosos por convento a lo que se añaden 10 criados de media por institución (eran el 20,5\% de los albergados entre sus paredes). Los conventos femeninos eran 11. En su interior se hallaban 336 personas, el 24,4\% (82 personas) eran servidumbre contratada. De media, habitaban sus edificios 23 religiosas y $7 \frac{1}{2}$ criados. Siete colegios reunían entre sus muros a 99 personas, con una media de 14 personas por inmueble. Los criados suponían el 19,2\% de sus miembros. Además, 36 clérigos, sobre todo de rango medio, compartían suelo, de manera dependiente, con familiares jefes de hogar — padres, hermanos, etc.-. 


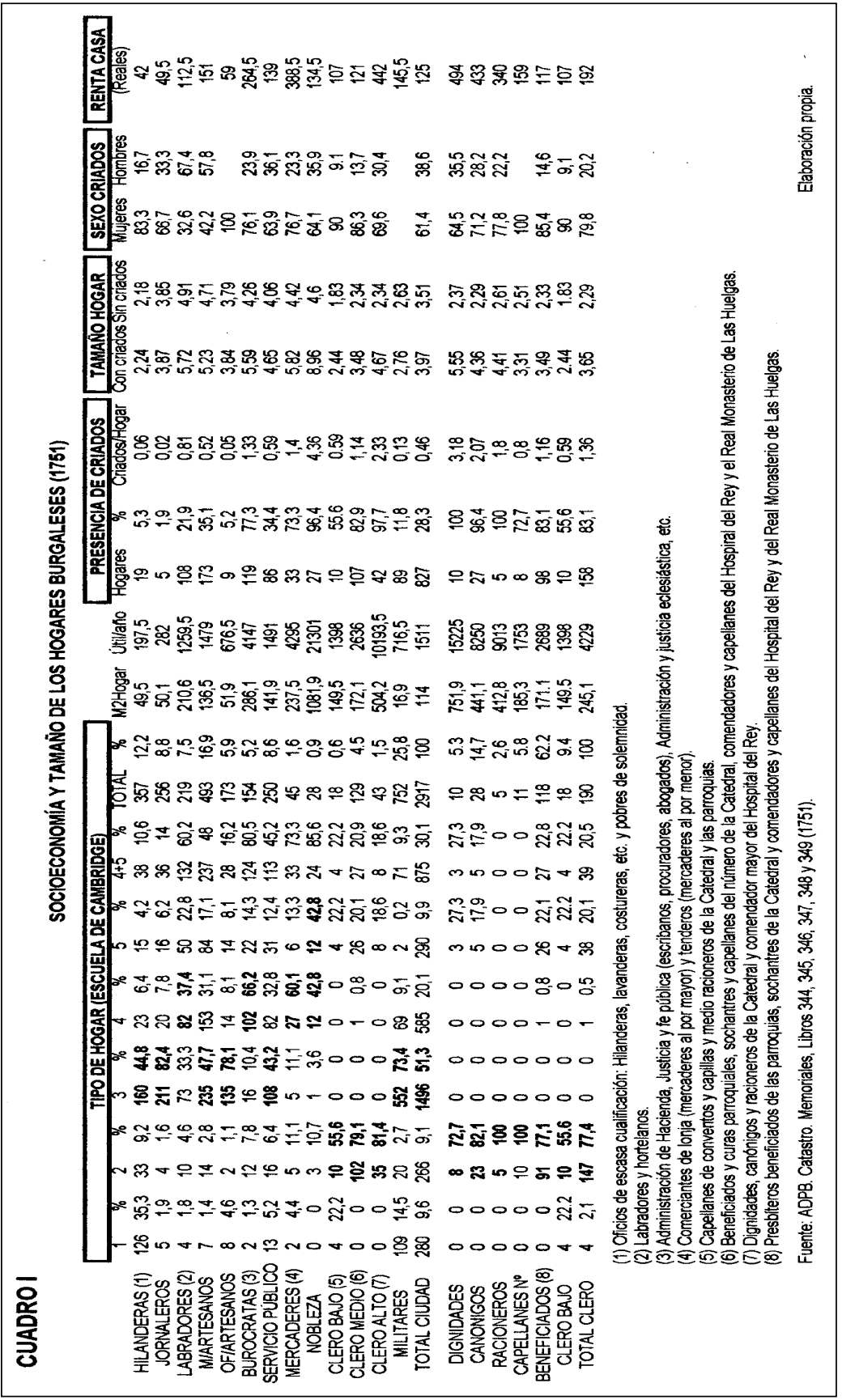

Hispania Sacra, LVIII

118, julio-diciembre 2006, 545-577, ISSN: 0018-215-X 
tiempo y rentas en abundancia para disfrutar, incluso, de algún momento de entretenimiento ${ }^{14}$.

Desde la perspectiva de la corresidencia y la economía doméstica, el clero medio-alto burgalés ${ }^{15}$ se asimilaba a las gentes de la burocracia y del comercio $^{16}$ — véase cuadro I- Estos eclesiásticos se colocaban entre la posición inalcanzable que tenía la nobleza más encumbrada ${ }^{17}$-muy por encima en todos los parámetros - y los otros peldaños, los más degradados, de la pirámide estamental. El clérigo de rango medio-alto vivía en condiciones aceptablemente satisfactorias si lo comparamos con labradores y hortelanos, maestros artesanos, gentes de los servicios públicos ${ }^{18}$ y con el clero bajo. Los jornaleros, oficiales artesanos, oficios escasamente cualificados - hilanderas, lavanderas, costureras, etc.- , tropas militares y pobres de solemnidad — se debatían cotidianamente entre el miasma y el hambre. La estrechez de sus habitáculos y la exigüidad de sus economías constituyen un verídico resumen de su endeble y tormentosa existencia. La soledad paupérrima ó el compartir las miserias en los hogares simples eran norma común. La nobleza y la burguesía ad hoc mantenían hogares extensos ó múltiples ${ }^{19}$. El clero se entretenía en otros derroteros.

14 Véase las publicaciones de BARRIO GOZALO sobre el clero en general y los arzobispos en particular y las ya citadas de F. J. Aranda Pérez (coord.), Rey CASTelao y BARReiro Mallón. Sobre las diversiones del clero burgalés — música doméstica y naipes y mesa de trucos públicos— F. SANZ DE LA Higuera: «Lugares para el ocio en el Burgos del XVIII. Una aproximación socio-económica», Stvdia Historica, 27 (2006) (en prensa).

15 Sin desmerecer en absoluto las propuestas del profesor Dubert García, me permito segmentar al clero burgalés en tres rangos diferentes. Como se comprueba en el cuadro I, a mi juicio esta matización es adecuada, dado sus niveles de ingresos, dimensiones de las viviendas y presencia de criados en sus hogares. El clero alto estaba compuesto por las dignidades, canónigos y racioneros de la Catedral y el comendador mayor del Hospital del Rey. El clero medio por los beneficiados parroquiales, los sochantres y capellanes del número de la Catedral y los capellanes y comendadores del Hospital del Rey y el Real Monasterio de Las Huelgas. En última instancia, el clero bajo tendía entre sus filas a los eclesiásticos dedicados a la administración y atención religiosa de conventos, monasterios y hospitales y a los medios racioneros de la Catedral y las parroquias de la ciudad.

16 Fueran pecheros, hidalgos o nobles de sangre, se trata de la burguesía urbana, encargada de la administración de las Rentas Reales (Hacienda), la gestión de la fe pública y el derecho (escribanos, procuradores, notarios, abogados, etc.), el abastecimiento de mercancías a la población.

17 Dentro de este selecto grupo de hogares se contempla a los titulados y caballeros —en su inmensa mayoría regidores perpetuos del Concejo- y a la nobleza de sangre sin implicaciones en el gobierno municipal, viudas incluidas, que viven de las rentas de sus mayorazgos y de sus propiedades libres.

18 Obligados de los abastecimientos públicos, individuos implicados en la sanidad y la enseñanza, mesoneros, posaderos y taberneros, caleseros y alquiladores de mulas, cocheros (públicos y privados), servicio doméstico y empleados municipales y eclesiales.

19 R. TORRES SÁnchEZ: «El hogar del burgués», L. M. Enciso Recio (coord.): La burguesía española en la Edad Moderna, Valladolid, 1996, pp. 253-268, y F. GARcíA GonZÁleZ: La Sierra de Alcaraz en el siglo XVIII. Población, familia y estructura agraria, Albacete, 1998, pp. 207-247 y Las estrategias de la diferencia. Familia y reproducción social en la Sierra. (Alcaraz, siglo XVIII), Madrid, 2000, pp. 241-307. 
Las dimensiones de los hogares del clero de Santiago de Compostela - 56 individuos en el Palacio arzobispal y 7,1 entre los canónigos- les equiparan a la nobleza ${ }^{20}$. En Burgos, todo es más modesto. Las 27 personas albergadas en el hogar arzobispal (1744) ${ }^{21}$ y las 4,7 de los hogares de los canónigos (1751) nos ofrecen una perspectiva cercana a una ciudad más enjuta y marginal. La media del tamaño de los hogares de la nobleza más encumbrada $-8,9$ miembros por hogar- sólo es alcanzada por un reducido número de dignidades — por ejemplo, don Juan Antonio Garma de la Puente ó don Diego Zamora Huidobro- ó algunos canónigos — don Diego de Haedo ó los hermanos Ojeda SalazarNos encontramos, incluso, con una paradoja tremenda. Las dimensiones medias de los hogares de los clérigos $(3,9)$ se equiparan a los hogares medios de los jornaleros $(3,9)$ y de los oficiales artesanos $(3,8)^{22}$ — cuadro I- .

El gráfico I muestra el contraste entre clérigos y nobleza rentista. Su aspecto general es más o menos similar al recogido por Dubert para Santiago de Compostela $^{23}$. La citada nobleza se encuadraba en hogares ensanchados ó múltiples con el umbral de los 7 a los 9 miembros como predominante. El clero apostaba por hogares sin estructura familiar con 2 a 5 personas en su interior.

Otro aspecto substancial para demostrar las hipótesis de este trabajo es el grado de feminización del servicio doméstico, y de los familiares, existente en los hogares eclesiásticos y las similitudes ó discordancias que tenía con otras categorías profesionales - véase cuadro I y gráfico II-. Las dignidades y canónigos de la Catedral, con un nivel de masculinidad del personal doméstico situado entre el 30 y el $35 \%$, se asemejan en sus comportamientos a la nobleza más encumbrada (35,9\%). A mayor altura en el escalafón clerical más masculinización de la servidumbre y de los familiares agregados. Los racioneros de la Catedral se encontraban en un espacio intermedio (22,2\% de criados). A medida que bajamos en la pirámide de los rangos eclesiásticos el grado de feminidad es mayor - $100 \%$ entre los capellanes del número de la Catedral, 90,9\% en el clero bajo y 85,4 en el clero medio- . Al clero medio-bajo burgalés le atraía la feminidad y llenaba las estancias de sus viviendas con criadas y madres, hermanas, sobrinas, familiares de parentesco indeterminado, etc. La masculinización se extendía, entre el clero alto, también a los familiares acogidos: el 60\%, de promedio, eran capellanes del número («familiares») y sobrinos.

20 I. Dubert García: Historia de la familia en Galicia,..., La Coruña, 1992, pp. 172-176, y W. A. ARMSTRONG: "A note on household structure of mid-XIX century York in comparative perspective», Household and Family in past time, Cambridge, 1974, pp. 205-215.

21 AHPB. PN. Legajo 6983 (1744). Inventario de don Diego Felipe de Perea, arzobispo de Burgos.

22 La estructura interna de esos hogares era muy diferente. Los proletarios — sean del campo o de los talleres artesanales - tenían hijos, sin ningún personal contratado. El clero albergaba a familiares y al servicio doméstico. Las dimensiones de sus cuartos-casa y de sus alcances anuales patentizan el amplio espacio que separa la estrechez, el hacinamiento y el hambre de la comodidad y la satisfacción.

23 I. Dubert García: «Los comportamientos familiares...», Compostellanum, 31 (1986), p. 453. 


\section{GRÁFICO I}

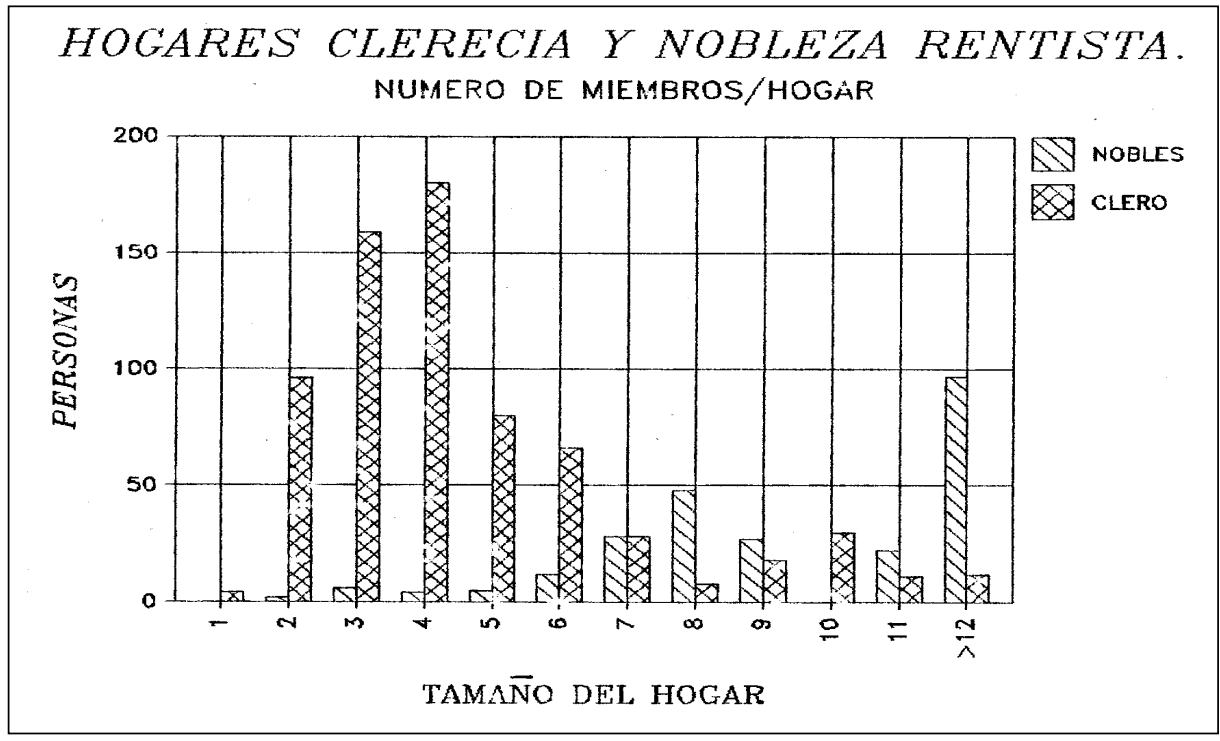

GRÁfICO II

GRADO FEMINIZACION PARIENTES AGREGADOS. HOGARES ECLESIASTICOS: BURGOS 1751.

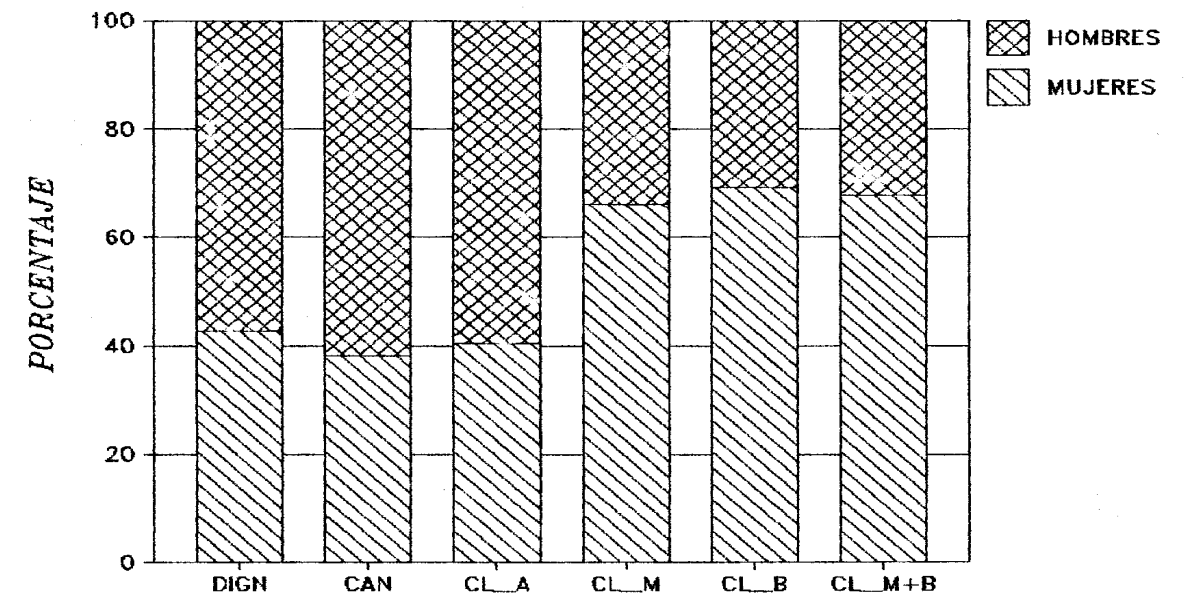

DIGN= Dignidades. $\mathrm{CAN}=$ Canónigos. $\mathrm{CL} \_\mathrm{A}=$ Clero Alto. $\mathrm{CL} \_\mathrm{M}=$ Clero Medio. $\mathrm{CL} \_\mathrm{B}=$ Clero Bajo. 
De promedio, el 77,5\% de los hogares de los clérigos con vivienda en la ciudad de Burgos era un establecimiento sin estructura familiar (TIPO 2), es decir, sus componentes mantenían una corresidencia no basada en el matrimonio. Únicamente en cuatro ocasiones al eclesiástico es admisible colocarle la etiqueta de solitario $^{24}$. Esa circunstancia significa un modesto 2,1\% del total de los hogares de las gentes de Iglesia. Empero, ese reducido porcentaje suponía un más que anecdótico $22 \%$ de los establecimientos habitados por el clero bajo, peculiar situación que sólo a ellos afectaba. El clero restante al parecer no podía soportar vivir completamente en soledad. Con criadas y/o familiares residían el $55,6 \%$ de los clérigos de bajo rango. Estos clérigos de reducidos ingresos comandaban en otro $22,2 \%$ hogares múltiples - del TIPO 5 según las propuestas laslettianas -, merced a la corresidencia, bajo los mismos techos de la misma vivienda, de dos núcleos diferentes de relación familiar o para-familiar.

Los solitarios presentan unas características bien definidas. Por una parte, descuellan don Baltasar de la Cuesta y don Ventura de Monasterio, residentes ambos en la calle Lencería, en las inmediaciones de la Catedral. Formaban parte del proletariado eclesial, del clero mercenario y pluriempleado ${ }^{25}$. Don Baltasar era medio racionero en la Catedral y capellán en la capilla de la Concepción, empleos en los que obtenía poco más de 550 reales. A ello se añadían 200 reales procedentes de unas propiedades foráneas. Vivía «de posada en el Usillo» y pagaba «diez reales al mes a Phelipe Santos, barrendero» por su cuidado y asistencia ${ }^{26}$. Don Ventura, de 37 años en 1751, era «capellán de servicio de don Phelipe Carrera», quehacer por el que conseguía 220 reales/año. Ocupaba un cuarto en el usillo, de posada: abonaba 30 reales al $\mathrm{mes}^{27}$.

${ }^{24}$ La tipología del Grupo de Cambridge, aunque discutible y discutida en muchos aspectos, es útil a efectos prácticos como referencia sencilla, funcional y de contraste para analizar la estructura y el tamaño de los hogares. De una manera escueta, se puede resumir en la consideración de un TIPO 1, «Solitario», TIPO 2, «Hogar sin estructura familiar», TIPO 3, «Hogar nuclear», TIPO 4, «Hogar ensanchado» y TIPO 5, «Hogar múltiple». Comparto las reflexiones de DuBERT sobre las características del grupo doméstico pero entiendo que, a pesar de todo, un hogar no requiere la existencia ineludible de lazos de sangre. Las personas que comen, duermen y velan bajo los mismos techos conforman un hogar. En los vecindarios, censos y libros de matrícula parroquiales así se hace constar. I. DUBERT GARCíA: Ibidem, p. 443.

25 También cabía la posibilidad de tener un mísero y único empleo que a duras penas daba para comer y pagar el alquiler del cuarto-casa, de posada, en que se cobijaban. Se dan ambos extremos, como va a quedar reflejado. Véase los comentarios de J. BRAVO LOZANO: «Cura rico/cura pobre...», pp. 129130, y F. SANZ DE LA HIGUERA: «"Un capellán que sirve la mesa" y otros menesteres. Burgos a mediados del siglo XVIII», Stvdia Historica, 24 (2002), Salamanca, pp. 331-362. En las urbes preindustriales este clero flotante carecía de un beneficio que les atara de forma continua a una parroquia.

26 ADPB. Catastro. Memoriales, B, Libro 348, folios 64-65 y Libro 437 (Castañares). No dispongo de su testamento. Probablemente falleció ab intestato, como era norma común entre los más paupérrimos.

27 Ibidem, B, Libro 348, folio 70. Sin testamento.

Hispania Sacra, LVIII

118, julio-diciembre 2006, 545-577, ISSN: 0018-215-X 
Es también significativo, por otra parte, el acontecer de don Santiago Ruiz Quintana y Haedo, de 47 años, quien ejercía como capellán de la capilla del Ecce homo y San Enrique (669 reales/año), capellán en la capellanía de Santiago de la Capilla y acólito del acolitazgo fundado por don Diego de Melgosa. Por beneficios simples en Cascajares, Quintanilla Bón y Villaescusa de Butrón ingresaba al año casi 2.500 reales. De él se dice en el Catastro que «no tiene familia aunque le ayuda la familia de don Francisco Páramo, pertiguero mayor» de la Catedral ${ }^{28}$. Ambos ocupan los cuartos del entresuelo a los pies de la residencia de don Rafael Antonio Gil Delgado, en la calle de los Avellanos ${ }^{29}$. Por las estancias del «entresuelo que miran al río» - aproximadamente $187 \mathrm{~m}^{2}$ - pagaba anualmente el clérigo 200 reales $^{30}$. En última instancia, los cuartos de la sacristía de la parroquia en la que era sacristán mayor (317 reales) y medio racionero (325 reales) eran la habitación de don Tomás González Ramírez, clérigo «sin familia». Sus escasos ingresos anuales propiciaban los reducidos $731 \frac{1}{2} \mathrm{~m}^{2}$ que ocupaba en la citada sacristía, ubicada en el barrio de Viejarrúa ${ }^{31}$.

Sólo en una ocasión —el 0,5\% del total de los eclesiásticos- hallamos a un individuo enviudado y dado a la profesión religiosa. Convivía con sus hijos y el personal doméstico bajo el techo de un mismo hogar. Beneficiado en la parroquia de San Cosme y San Damián, él mismo señala en sus testamentos que era «viudo de doña Josefa Senar y Alvarado, por cuio fallecimiento me dediqué al estudio y me hize como lo soy presbitero...». Dos de sus tres hijos se habían acogido también a la vida religiosa. Eran los más jóvenes. El mayor, teniente de granaderos de milicias, se encontraba en casa, mantenido «por encontrarse sin sueldo ni remuneración desde la Retirada general de la tropa en Italia». Don Ildefonso Antonio de Pando, que así se llamaba el clérigo previamente enviudado, era consciente de las circunstancias que les tocaban vivir — «Respectto a mis Cortos vienes» afirmaba literalmente - pero era muy cariñoso con su progenie - «que con ellos e echo en su acomodo y alimenttarlos» los gastos imprescindibles-. Marcos Nicolás redactó de su propia mano un excelente memorial en el que nos da cuenta de su economía personal y admite, sin rubor, que con ello «contribuye a su padre (...) (en cuia casa vivo) para ayuda de mi ma-

28 Ibidem, F, Libro 344, folios 931-932. En su calidad de administrador de las casas del marqués de Silleruelo, propietario del edificio, la vivienda la obtenía gratuitamente.

29 Ibidem, R, Libro 345, folios 16-21. Don Rafael estaba al frente de un hogar múltiple, (5a)9, era señor de Bascones del Agua y subdelegado para la Única Contribución. Su útil anual rondaba los 42.000 reales. Al fallecer se le efectuó un post-mortem: su caudal ascendía a 370.000 reales. AHPB. PN. Legajo 7224 (1788), folios 425-462. El contraste entre el arriba y el abajo, entre la soledad y el gentío, la pobreza y la riqueza es auténticamente abismal. La diferenciación social en altura es concluyente.

30 ADPB. Catastro. Memoriales, S, Libro 349, folio 589, Libro 430 (Cascajares), Libro 1527 (Quintanilla Bón) y Libro 2244 (Villaescusa de Butrón).

31 Parroquia de Nuestra Señora de La Blanca y San Andrés. ADPB. Catastro. Memoriales, T, Libro 349, folios 597-598. Tampoco se ha hallado su testamento, síntoma de debilidad económica. 
nutención, que no pudiera ser sin esta unión». El edificio en que habitaban, sito en el barrio de la Yedra (Santa Dorotea), era modesto pero de su propiedad, hecho muy poco usual. Entre los cuatro obtenían un útil cercano a los 3.000 reales, el doble que el promedio de la ciudad, con el que satisfacían la contratación de una criada (74 reales/año), residente en la casa y los servicios de un sangrador y barbero y una lavandera. El hogar resultante es un núcleo familiar ensanchado por razones laborales, $(4 \mathrm{c}) 5^{32}$.

La inmensa mayoría de los eclesiásticos —el 77,4\%— residían en hogares sin estructura familiar (TIPO 2), en compañía del servicio doméstico y/o de familiares de distinta procedencia. Es obvia la existencia de ciertas diferencias entre los clérigos que es preciso matizar. El porcentaje más reducido - 55,6\%- lo hallamos entre el bajo clero. La razón es significativa. Estos individuos vivían de forma solitaria, sin ninguna compañía diurna ó nocturna bajo sus techos, en un $22,2 \%$ de los $\operatorname{casos}^{33}$.

Entre los racioneros y los capellanes del número de la Catedral — cuadros I y II-, el TIPO 2 es la única manera de convivencia recopilada. Los capellanes del número no corresidían en ningún caso únicamente en compañía del servicio doméstico. En un 72,7\% lo hacían conjuntamente con familiares y con criadas. En un 27,3\% aparecen únicamente familiares a su lado. Don Francisco Gil Espiga es un ejemplo del primer tipo de corresidencia. Los $136 \mathrm{~m}^{2}$ de su vivienda en San Cosme eran ocupados por el clérigo, una sobrina, tres familiares de parentesco indeterminado, dedicados a la «enseñanza de la doctrina y a la labor de media» y una criada. Sus ingresos les permitían mantener una existencia más o menos decorosa, sin excesivas alegrías pero lejos de las carencias y sufrimientos de gran parte de la población. Lo más usual era mantener una criada, o ama, y una ó dos sobrinas huérfanas ${ }^{34}$.

32 Del militar dijo el padre, con pesar y aflicción, «me ha asistido siempre». En el entresuelo se localizaban una caballeriza pequeña, una despensa, el portal, un corral —usado como jardín, con 13 árboles-y, en su seno, «un quarto a modo de cenador». En la vivienda se desplegaban tres estancias (dormitorios). Los desvanes eran inhabitables, según sus propias palabras. Los suelos útiles para la convivencia suponían aproximadamente $180 \mathrm{~m}^{2}$. Sobre las viviendas del clero, véase en especial I. DuBERT GarCía: «Los comportamientos familiares...», Compostellanum, 31 (1986), pp. 447; B. BARREIRO MALLÓN: «Las clases urbanas de Santiago en el siglo XVIII...», Historia social de Galicia..., 1981, p. 453, y F. SANZ DE LA HigueRA: «Familia, hogar y vivienda en Burgos...», Investigaciones Históricas, 22 (2002), Valladolid, pp. 187-211. ADPB. Catastro. Memoriales, I, Libro 349, folio 348 y M, Libro 349, folio 479. Los testamentos de don Ildefonso en AHPB. PN. Legajo 7089 (1750), folios 305-306 y Legajo 7119/2 (1766), folios 254-256.

${ }^{33}$ La extrema debilidad económica generaba soledad. Otro no menos notable 22,2\% comandaba hogares del TIPO 5 con dos ó más núcleos domésticos en su interior. La lucha contra el desamparo y la pobreza aliaba a los parientes y les obligaba a corresidir en un mismo espacio, fueran edificios completos o cuartos-casas. Aunar ingresos, suavizar gastos y darse apoyo y compañía posibilitaba la supervivencia.

${ }^{34}$ Se daba cobijo a las sobrinas y sobrinos para fomentar el estudio y posibilitar el «tomar estado», recurso imprescindible, junto con el convento y la servidumbre, para unas mujeres huérfanas que 


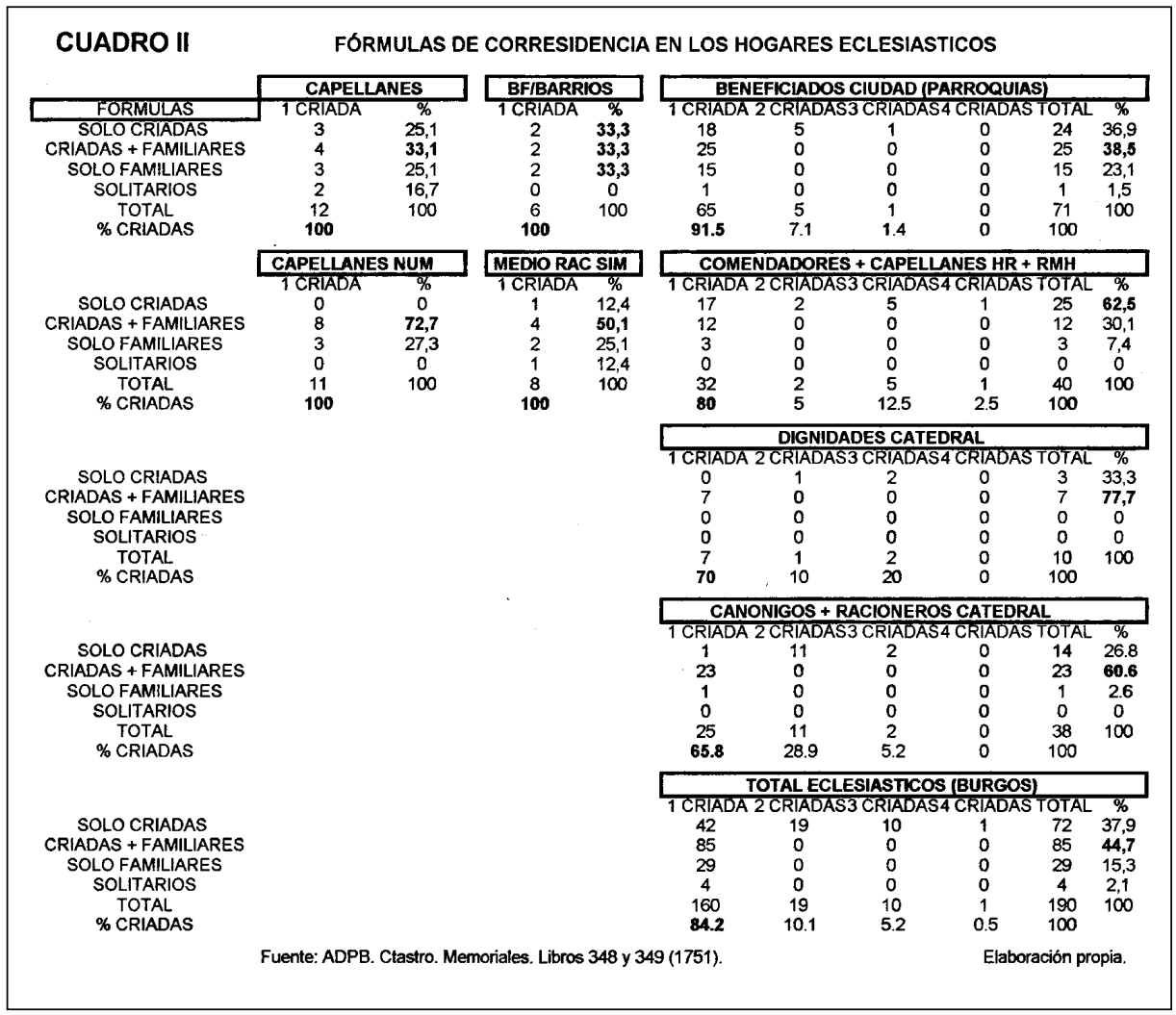

Don Sebastián Basabé, con una hermana a su cargo ${ }^{35}$, ó don Juan Ruiz de Mirones, al cargo de tres familiares de parentesco indeterminado, — ambos sin servicio doméstico- representan la segunda opción. La expresión «asistencia con cama y cocina gratuitamente» resume con nitidez el tipo de relación entre

hubieran caído en las garras del desamparo de no mediar su pariente clérigo. Don Francisco era capellán del número y de la capilla de la Visitación en la Catedral y ocupaba el curato del Hospital de La Concepción. La vivienda tenía un complemento ideal en un «jardín regado a pie» de $229 \mathrm{~m}^{2}$ de superficie. Véase, para este y otros casos, D. FAUCHER: «Les jardins familiaux et la Technique agricole», Annales ESC, 14 (1959), París, pp. 297-307. ADPB. Catastro. Memoriales, F, Libro 349, folio 195. Sin testamento.

35 Don Sebastián era capellán del número en la Catedral y capellán y mayordomo en un convento de la ciudad. Residía en el barrio de Vega, cerca del convento de San Pablo, en un edificio que le ofrecía $68 \mathrm{~m}^{2}$ de suelos que compartir con su hermana. Su alcance anual, 2115 reales, les permitía vivir sin estrechez aunque con moderación. ADPB. Catastro. Memoriales, S, Libro 349, folio 591. Sin testamento. 
ellos existente ${ }^{36}$. Los racioneros nos muestran una estrategia completamente diferente. Su economía doméstica es la responsable de tal situación: el promedio anual de sus alcances era cinco veces mayor. Algo más de la mitad - 57,2\%se recogían en compañía de familiares y criadas. Don José Saiz de Santuola albergaba en su casa y compañía a una criada y a cinco sobrinas de diferentes edades. Con 11.000 reales/año y $500 \mathrm{~m}^{2}$ de suelos, su existencia era bastante agradable ${ }^{37}$. La otra mitad $(42,8 \%)$ recurría exclusivamente a los domésticos como única fórmula de convivencia. Don José Antonio Merino vivía «sin familia» y recurría a dos criadas y a un criado estudiante de gramática, a quien se acogía de limosna, para cubrir sus necesidades cotidianas ${ }^{38}$.

Las dignidades de la Catedral — cuadros I y II — hilvanaban su existencia a través de hogares sin estructura familiar. La estrategia de convivencia más usual era hallar bajo el mismo techo a familiares y criados en compañía del clérigo - $70 \%$ de los hogares-. Un ejemplo paradigmático lo encontramos en don Ramón de Larrínaga. El abad de San Quirce reunía entorno a sí a un familiar de parentesco indeterminado — una «excriada, como de la familia»-, dos criadas, un criado estudiante y un cochero, quien recibía anualmente su salario, una librea entera y habitación. Tanto la casa mansión que ocupaban — con casi $900 \mathrm{~m}^{2} \mathrm{de}$ suelos habitables - como su nivel de rentas, cuatro veces superior a la media de la ciudad, posibilitaban una vida cómoda y agradable ${ }^{39}$. Don Diego Escalona, compadre de don Ramón en la cúspide de la mesa capitular, reunía en su casa a un criado, un ama, una cocinera, un capellán de número - familiar suyo de pa-

${ }^{36}$ Don Juan era también capellán del número. Los ingresos procedentes de ese empleo los completaba con sus quehaceres como capellán en la capilla del Condestable, en la Catedral, y un escaso caudal procedente de un beneficio simple en un pueblo cercano. Su vivienda se encontraba en la calle San Lorenzo (300 m²). 2.600 reales/año de útil daba de comer a las cuatro personas. ADPB. Catastro. Memoriales, J, Libro 349, folio 401. Testamento en AHPB. PN. Legajo 7191 (1773), folios 220-222.

37 Vivienda en propiedad en San Lorenzo. Era el único de los racioneros, y aún de los miembros de la Catedral en su conjunto, con esa circunstancia, que sólo le ocurría al 7,4\% de los clérigos de la ciudad. ADPB. Catastro. Memoriales, J, Libro 349, folio 359. Testamentos en AHPB. PN. Legajo 7012 (1746), folios 269-273 y Legajo 7056/2 (1764), folios 165-166.

38 Don José Antonio era racionero y maestro de ceremonias en la Catedral, empleos en los que obtenía, junto con las rentas conseguidas en varios pueblos de la provincia, más de 7.000 reales/año. Rebajado un $20 \%$ por los gastos habituales (alquiler, criadas, etc.), su útil anual era envidiable y le permitía habitar en la elitista calle Abades sobre casi $300 \mathrm{~m}^{2}$ de suelos habitables. ADPB. Catastro. Memoriales, J, Libro 349, folio 403. No dispongo de su testamento.

${ }^{39} \mathrm{Su}$ IPM lo asevera con rotundidad. Se le inventariaron pertenencias por un total de 116.000 reales. Sobre don Ramón, véase R. J. PAYo HerRanz: Arte y sociedad en Burgos en la segunda mitad del siglo XVIII, Burgos, 2003, pp. 18-19, 34-38, 79, 89 y 136-138; F. SANZ DE LA HIGUERA: «Familia, hogar y vivienda en Burgos...», Investigaciones Históricas, 22 (2002), Valladolid, p. 208, y «Una estancia doméstica que se mueve. Entre las calles y las casas de Burgos a mediados del XVIII», Cuadernos de Investigación Histórica, 21 (2004), Madrid, pp. 469-506. ADPB. Catastro. Memoriales, R, Libro 349, folios 587-588 y AHPB. PN. Legajo 7268 (1773), suelto (IPM). Rubricó ocho testamentos entre 1747 y 1773 , record absoluto en la redacción de últimas voluntades en la ciudad de Burgos.

Hispania Sacra, LVIII

118, julio-diciembre 2006, 545-577, ISSN: 0018-215-X 
rentesco indeterminado de quien se dice estaba «al servicio de don Diego», razón por la cual percibía «mantenimiento, comida, vestido y habitazión»- y a una anciana de más de 70 años, también familiar lejano ${ }^{40}$. No se encuentra ningún caso de convivencia con familiares exclusivamente. En un 30\%, el dignatario catedralicio aparece en corresidencia con el servicio doméstico. Dos ejemplos evidentes son el hogar de don Domingo Río y Cantolla y el de don José Pérez Aguilar. Don Domingo comandaba un hogar en el que un ama, una criada y un criado estudiante, «sin paga», le servían de compañía. Los más de 16.000 reales que obtenía de ingresos al año le permitían satisfacer el alquiler de una enorme casa mansión, los salarios del servicio doméstico y «sustentar a dos sobrinos, profesores de jurisprudencia en la Universidad de Valladolid». Era una vivienda de canónigo de casi $800 \mathrm{~m}^{2}$ de suelos habitables, la cual disponía de 6 ó 7 estancias en las viviendas, un soleador, varios desvanes y un entresuelo en el que el portal, un patio y unas trojes $\left(\mathrm{de} 28 \mathrm{~m}^{2}\right)$ rivalizaban con caballerizas y establos $^{41}$. Don José era más modesto en todo -11.000 reales de útil y $500 \mathrm{~m}^{2}$ de suelos- pero aún así se rodeó de un ama y dos criadas ${ }^{42}$.

En un 30\% de los casos aparece un más que significativo recurso al hogar múltiple. Don Diego Zamora Huidobro ${ }^{43}$ tenía en su entorno a cinco primos, todos ellos hermanos, una sobrina y tres criados (un paje estudiante y dos criadas de servicio). Doña Juana Huidobro declaró en su memorial, en el que también aparecen Bartolomé y Juan Ramón, sus hermanos, que «vive en compañía del Capiscol (...) su primo». El útil anual obtenido por todos ellos —un impresionante volumen de dinero y productos en especie cercano a los 30.000 realesno se veía reflejado en las dimensiones de su vivienda, en la que sin llegar al hacinamiento no parece que estuvieran exentos de cierta estrechez $\left(280 \mathrm{~m}^{2}\right)$. Don Juan Antonio Garma de la Puente resume todos los asertos que sobre con-

40 Don Diego reunía en sus manos la dignidad de magistral de la Catedral, tesorero de la Mesa Capitular, canónigo y varios beneficios simples. Rebajados los gastos (23\% de los ingresos), la economía doméstica de este hogar disfrutaba de una más que satisfactoria posición. Vivía, a mediados de 1751, en una casa del barrio de San Estaban, minúscula $\left(105 \mathrm{~m}^{2}\right)$ pero para San Juan de ese año se trasladó a un edificio de la calle San Lorenzo que, aunque duplicaba el valor del alquiler (600 reales/año) le ofrecía el triple de espacio habitable $\left(345 \mathrm{~m}^{2}\right)$. ADPB Catastro. Memoriales, D, Libro 349, folio 45 . Testamento en AHPB. PN. Legajo 7082 (1755), folios 189-196.

41 Maestre escuela y canónigo en la Catedral. Residía en la calle San Lorenzo. ADPB. Catastro. Memoriales, D, Libro 349, folio 36. Testamentos en AHPB. PN. Legajo 7013 (1747), folios 174-175 y Legajo 7209 (1763), folios 119-120.

42 Arcediano de Lara y canónigo en la Catedral y beneficiado simple en Huerta de Arriba. ADPB. Catastro. Memoriales, J, Libro 349, folio 415. No dispongo de ningún testamento.

43 Capiscol y canónigo, era también capellán mayor de la capilla de La Purificación. Calle Pellejería. Dos de los citados primos eran también eclesiásticos. Don Bartolomé, canónigo coadjutor, y don Juan Ramón, arcipreste de Losa. ADPB. Catastro. Memoriales, D, Libro 349, folio 44, B, Libro 348, folio 48, J, Libro 349, folios 416-417 y J, Libro 345, folios 297-298. Testamento en AHPB. PN. Legajo 7025 (1760), folios $175-176$. 
vivencia en un hogar múltiple se quiera analizar. No sólo albergaba junto a sí a un individuo de parentesco indeterminado en calidad de «familiar» sino que el servicio doméstico que tenía contratado era auténticamente descomunal, como lo eran las dimensiones de la casa mansión que tenía alquilada en la céntrica y elitista plaza del Huerto del Rey $\left(1.100 \mathrm{~m}^{2}\right)$ y los alcances anuales que se les pueden adjudicar - cercanos a los 25.000 reales - . Disponían de tres criadas, un paje, un cochero y dos criados de librea, uno de los cuales estaba casado y recibía, además de 600 reales/año, mantenimiento y habitación en el seno de la citada mansión. El otro criado de librea vivía de manera independiente. Nos hallamos ante un hogar múltiple, con dos núcleos de parentesco, por razones laborales, $(5 \mathrm{c}) 9^{44}$. Don Alonso Isla Venero era más modesto. Reunía en su entorno a dos sobrinos, albergados para cursar estudios, a un criado y a dos criadas, hermanas entre sí. Se trata también de un hogar múltiple, (5c)6, de sesgo laboral. Los aproximadamente 15.000 reales de útil anual que restaban de conjugar ingresos y gastos permitían mantener, con holgura y satisfacción, un edificio imponente en La Calera, con $700 \mathrm{~m}^{2}$ de suelos habitables, complementados con un magnífico jardín de 420 $\mathrm{m}^{2}$, preñado de árboles frutales, y un corral de 80 metros cuadrados ${ }^{45}$.

Los canónigos - cuadros I y II - eran, después de los racioneros y los capellanes del número, quienes más se acomodaban en hogares sin estructura familiar. El 82,2\% de ellos se encuadraba en el TIPO 2, mientras que sólo el 17,8\% era responsable de hogares múltiples (TIPO 5). Una parte importante de estos clérigos compartían su espacio con familiares y criados $(57,1 \%)$. Don Román García Velarde y su sobrino carnal, también canónigo, disponían de dos criadas y dos criados estudiantes y licenciados para su servicio. A éstos últimos sólo se les daba cama y comida como retribución. Su economía doméstica era muy solvente, con casi 15.000 reales de útil anual. Con tales rentas sufragaban el alquiler de dos casas contiguas - las cuales les permitían disponer de casi $400 \mathrm{~m}^{2} \mathrm{de}$ espacio para la convivencia- y los salarios y mantenimiento de los criados ${ }^{46}$.

44 Arcediano, señor y juez ordinario de la villa de Valpuesta, reunía en su mano una dignidad y una canonjía catedralicia y varios beneficios simples en diferentes pueblos de la provincia. Su post-mortem computó una cifra cercana a los 65.000 reales. AHPB. PN. Legajo 7164 (1754), folios 196-203. Véase F. SANZ DE LA HigUERA: “"Un capellán que sirve la mesa”...», Stvdia Historica, 24 (2002), Salamanca, pp. 331-362 y «Una estancia doméstica...», Cuadernos de Investigación Histórica, 21 (2004), Madrid, pp. 469-506. ADPB. Catastro. Memoriales, J, Libro 349, folio 349. Testamento en AHPB. PN. Legajo 7164 (1753), folios 179-180.

45 Arcediano de Treviño y canónigo en la Catedral, también reunía varios beneficios simples en sus manos. ADPB. Catastro. Memoriales, A, Libro 348, folio 21-22. Testamentos en AHPB. PN. Legajo 7009 (1742), folios 133-134, Legajo 7010 (1743), folios 595-597 y Legajo 7054/2 (1754), folios 183-184.

46 Residía en la calle Alta ó Tenebregosa. ADPB. Catastro. Memoriales, R, Libro 349, folios 583584 y J, Libro 349, folio 412. El caudal de su IPM ascendió a una impresionante cantidad, cercana a los 270.000 reales, uno de los más elevados de entre los clérigos burgaleses. AHPB. Justicia Municipal. Legajo 987 (1786), folios 9-85. Su testamento en AHPB. PN. Legajo 7031 (1766), folios 44-45.

Hispania Sacra, LVIII

118, julio-diciembre 2006, 545-577, ISSN: 0018-215-X 
Es también especialmente significativo el hogar de don Manuel Prieto Bustamante, quien ocupaba «gratuitamente», en compañía de su sobrino don Manuel Prieto, teniente agregado a la Plana Mayor, el cuarto del Rector del Seminario, cargo que desempeñaba su citado tío ${ }^{47}$. Conjuntamente con hermanos y personal doméstico vivían varios canónigos. El más significado, por su número, era don Francisco Ruiz Llanos, quien, junto a una criada, mantenía a tres hermanas. Ocupaba un edificio en la plaza del Sarmental, lugar en el que disponía de aproximadamente $105 \mathrm{~m}^{2}$ de suelo, dimensiones escasas para un canónigo que obtenía de útil al año algo más de 7.000 reales de vellón ${ }^{48}$. Sólo en una ocasión el eclesiástico compartía existencia con su madre y el servicio doméstico - una criada y un criado- - Se trata de don Tomás Antonio Garro. Ocupaba una casa en alquiler de enormes dimensiones $\left(1.730 \mathrm{~m}^{2}\right)$. El útil anual que lograba reunir, cercano a los 6.300 reales de vellón, era envidiable ${ }^{49}$. Combinaban la presencia de criados y familiares con parentesco indeterminado don Pedro de Terán ${ }^{50}$ y don Fernando Ortíz de Zárate ${ }^{51}$.

El 39,3\% de los canónigos compartían suelos, techos y paredes con el personal doméstico pero sin el auxilio ni la concurrencia de ningún pariente. Hallamos a estos clérigos en compañía de dos ó tres domésticos. Don Agustín Miranda disponía para las labores domésticas de dos criadas ${ }^{52}$. Don Juan Manuel Velasco, de un ama y un criado ${ }^{53}$. Don Manuel Rebellón Solórzano, de una criada y un paje ${ }^{54}$. Don Francisco Llarena y Salcedo, comisario de la Santa In-

47 Canónigo lectoral y rector del Seminario. ADPB. Catastro. Memoriales, M., Libro 349, folio 361. Testamento en AHPB. PN. Legajo 7031 (1766), folios 367-378.

48 ADPB. Catastro. Memoriales, F, Libro 349, folio 176. Testamento en AHPB. PN. Legajo 7019 (1754), folios 543-544.

49 Residía este canónigo en la céntrica calle Pellejería. «El canonicato esta(ba) hipotecado con una pensión de 1.022 reales al año», cantidad que percibía don Manuel Navarrete, oidor en la Chancillería de Valladolid. ADPB. Catastro. Memoriales, T, Libro 349, folios 593-594. Testamento en AHPB. PN. Legajo 7147 (1762), folios 88-89.

50 Don Pedro, canónigo penitenciario y rector del colegio de San Nicolás, tenía su residencia en dicho colegio $\left(364 \mathrm{~m}^{2}\right)$. Su útil anual ascendía a una cifra cercana a los 9.000 reales, cantidad con la que mantenía un hogar (2c)4, en el que él y dos familiares de parentesco indeterminado (un clérigo subdiácono y el otro estudiante de gramática) compartían el espacio con una criada. ADPB. Catastro. Memoriales, P, Libro 349, folio 564-565. No se ha encontrado testamento.

51 Canónigo, residente como los anteriores en la calle Abades, disfrutaba de un edificio en alquiler que le ofrecía $214 \mathrm{~m}^{2}$ para la convivencia con un ama, una criada y un familiar de parentesco indeterminado, estudiante de teología. ADPB. Catastro. Memoriales, F, Libro 349, folio 177. Sin testar.

52 Canónigo y administrador del Hospital de Barrantes, ocupaba el cuarto destinado a esos menesteres $\left(360 \mathrm{~m}^{2}\right)$. Útil anual cercano a los 7.700 reales. ADPB. Catastro. Memoriales, A, Libro 348, folios 23-24. No se ha detectado testamento.

53 Tenía su vivienda en la calle La Calera, en un inmenso edificio que les proporcionaba casi 700 $\mathrm{m}^{2}$ de suelos para la convivencia. Como la inmensa mayoría de los canónigos, su útil anual rondaba los 7.400 reales. ADPB. Catastro. Memoriales, J, Libro 349, folio 413. Testamento en AHPB. PN. Legajo 7003 (1733), folios 461-462.

54 En la calle Abades disponía de un edificio, propiedad como otros muchos alquilados por los ca- 
quisición, era atendido por un ama, una criada y un paje ${ }^{55}$. Los canónigos que convivían sólo con algún familiar eran muy escasos $(3,7 \%)$. El único hogar de esas características es el de don José Carrillo. Sobre $280 \mathrm{~m}^{2}$ hallamos al clérigo en compañía de una hermana, viuda, y un hijo de ésta, de edad pupilar. Su economía en nada era similar a la de los sufridos jornaleros o a la de los atareados $\operatorname{artesanos}^{56}$.

En el TIPO 5 hallamos cinco hogares, el 17,8\% de los canónigos. Los casos más sobresalientes son los protagonizados por don Diego de Haedo, don Diego y don Martín Ojeda Salazar - hermanos y clérigos ambos-y don Francisco Hernández Illana. Cada uno de ellos tiene una peculiaridad que les hace descollar especialmente. El hogar de don Diego de Haedo es muy curioso porque aparece el clérigo en compañía de un familiar de parentesco indeterminado, una criada y un cochero, Vicente Salinas, hombre casado y padre de cinco hijos, quien dijo ganar 900 reales/año y vivir en los «quartos vajos» de la casa mansión de su «amo», «gratuita por ser cochero de don Diego». La casa de las cuatro torres, propiedad del mayorazgo de los Brizuela, disponía de entresuelo — con el portal, las caballerizas, las estancias del cochero, establos, trojes, etc.—, «Quartos prinzipales» y «quartos altos». Los suelos útiles para la convivencia — aproximadamente $850 \mathrm{~m}^{2}$ - albergaban a las citadas personas y eran complementados por un jardín de $7.500 \mathrm{~m}^{2}$, repleto de árboles frutales. La muralla y la puerta Margarita eran testigos mudos de sus andanzas ${ }^{57}$. El hogar de los Ojeda Salazar no respondía al canon laboral precedente sino a la presencia de varios núcleos familiares unidos por el parentesco biológico. Don Diego comandaba un hogar (5c)9 en el que aparecen doña Teresa, su hermana, un sobrino, una criada y un criado. Además es notoria la presencia de otro sobrino, el citado don Martín, capellán del número, quien aportaba una hermana y dos sobrinos, hermanos, de edad pupilar, ambos estudiantes de gramática. En el memorial se advierte explícitamente de la importancia de las hermanas de cada uno de ellos, «a quienes asistimos en todo lo necesario». La casa en que habitaban les proporcionaba un espacio suficiente aunque no excesivo $\left(174 \mathrm{~m}^{2}\right)$ por el que pagaban 550 rea-

nónigos, que le proporcionaba casi $600 \mathrm{~m}^{2}$ de suelos útiles para la convivencia y un jardín de $76 \mathrm{~m}^{2}$, preñado de árboles frutales, para su disfrute. 7.000 reales/año. ADPB. Catastro. Memoriales, M, Libro 349 , folio 462 . No dispongo de testamento.

55 Plaza de Santamaría. 6.650 reales/año. Catastro. Memoriales, F, Libro 349, folio 168. Testamento en AHPB. PN. Legajo 7146 (1760), folios 525-526.

56 Calle Abades. 7.200 reales/año. Este alcance anual era 30 veces superior al de los jornaleros y 5 al de los artesanos. ADPB. Catastro. Memoriales, J, Libro 349, folio 407. Sin testamento.

${ }^{57}$ Era canónigo, abogado de los Reales Consejos y explotaba «granjerías» en varios pueblos. ADPB. Catastro. Memoriales, D, Libro 349, folio 37 y V, libro 347, folio 542. Al fallecer, su IPM supuso un minúsculo caudal, cercano a los 7.000 reales. La ruina atenazó los últimos años de su existencia. AMB. Histórica. Carpeta 1-9-14 (1780). Testamento en AHPB. PN. Legajo 7078 (1780), folios 180-181. 
les/año. La economía de este hogar estaba encuadrada en los umbrales más favorecidos de la sociedad burgalesa ${ }^{58}$. Don Francisco Hernández aunaba en su cercanía a una criada y a una hermana viuda, madre de una hija, su sobrina, menor de edad. Su vida cotidiana se desarrollaba en la calle Abades sobre $165 \mathrm{~m}^{2}$. El mantenimiento del hogar se efectuaba con los algo más de 7.000 reales al año ${ }^{59}$.

Entre el clero medio burgalés — cuadros I y II- se aprecia unos porcentajes casi semejantes a los hallados para las dignidades catedralicias. El 75,6\% conformaban, bajo su férula, hogares del TIPO 2 (sin estructura familiar), el 23,6\% presidian hogares de TIPO 5 (múltiples) y en un anecdótico $0,8 \%$ su titular era la cabeza visible de un hogar ensanchado - del que ya hemos dado cuenta anteriormente- Disponían de servicio en el 82,9\% de los hogares. Las criados y criados suponían un tercio de sus componentes (32,7\%). Habitaban casas de carácter mediocre - standard pobre-con $170 \mathrm{~m}^{2}$ de suelos habitables. Sus economías estaban ligeramente por encima del promedio burgalés, lejos de la aristocracia — en especial de la eclesiástica - pero sin el talante paupérrimo de la inmensa mayoría de la población ${ }^{60}$.

Estos hogares sin estructura familiar del clero medio burgalés tendían, de manera preferente, a estar compuestos por el eclesiástico y el servicio doméstico contratado. Con sólo criadas como única compañía vivían el 44,5\% de estos clérigos. Este hecho contrasta nítidamente con lo encontrado para el clero bajo (25\%) ó el clero alto (40\%). El cuadro II demuestra efectivamente importantes diferencias de corresidencia entre los miembros del clero. Resulta especialmente notoria la estrategia asumida por los capellanes del Hospital del Rey, quienes en un $65 \%$ eligen convivir en exclusiva con su servicio doméstico ${ }^{61}$. Los capellanes y comendadores del Real Monasterio de Las Huelgas no andan a la zaga. Dan alojamiento al servicio doméstico sin más acompañantes en un 57,9\% de los hogares. Se da aquí una especial circunstancia: el 100\% de esos clérigos recurre a una única mujer como criada. El contraste es nítido si comparamos los datos del clero medio con los computados para las dignidades catedralicias. Con la única compañía de una ó dos criadas aparece un escaso $30 \%$ de los hogares, aspecto que es casi equiparable al habido en las viviendas de los canónigos $(39,3 \%)$. Los datos extraídos de los hogares del clero bajo no pueden ser más elocuentes: los clérigos - capellanes de conventos y medios racioneros de la Catedral- compartían armarios, camas, mesas y manteles con una única

58 Plaza de Santamaría. 8.800 reales/año. ADPB. Catastro. Memoriales, D, Libro 349, folio 38.

59 Canónigo y maestro de capilla de la Catedral. ADPB. Catastro. Memoriales, F, Libro 349, folio 178. Testamento en AHPB. PN. Legajo 7115 (1757), folios 386-387.

60 Población llamada, por contraste, a la fatiga en el trabajo, la mendicidad en las calles, el hambre en las cocinas y la escasez de menajes en el lecho cotidiano.

61 El $46.1 \%$ con una criada, el $15,4 \%$ con dos y el $38,5 \%$ con tres. 
criada en el $16,7 \%$ de los casos. El 83,3\% restante procede de hogares en que, además del servicio doméstico, el clérigo tenía junto a sí a uno o varios familiares directos - madres, hermanas y sobrinos de ambos sexos, casi a partes iguales-.

Las agrupaciones domésticas del clero medio en que el eclesiástico convivía con familiares y criados suponían un 36,9\% - tanto entre el clero alto $(57,1 \%)$ como entre el clero bajo $(58,3 \%)$ eran predominantes-. En el 18,5\% de los hogares aparecen el clérigo y algún familiar cercano en corresidencia pero sin la necesidad de tener contratada ninguna criada - los familiares, generalmente hermanas, madres ó sobrinas, efectuaban las tareas esenciales de la casa-.

Don Juan Antonio Udías era capellán en un convento de la ciudad y beneficiado en un pueblo de las cercanías. No tenía servicio doméstico contratado. Lo suplía con la permanencia en su vivienda $-122 \mathrm{~m}^{2}$ - de una prima, acogida para efectuar las labores domésticas, es decir, como criada a todos los efectos. Junto a ellos aparece un sobrino, «estudiante de artes en San Pablo», el cual recibía «alimentación de limosna» ${ }^{62}$. Don Antonio Pérez, beneficiado en una localidad próxima y mayordomo de un convento, vivía en una casa del compás del convento, sin pagar renta por ser su cargo, en compañía únicamente de una criada $^{63}$. Don Benito Herrán, beneficiado en Ávila y capellán en Burgos, responde a la tercera vía, es decir, a la convivencia con un familiar — en este caso de parentesco indeterminado- y con una criada ${ }^{64}$.

Entre los beneficiados de los barrios próximos descuella don Fernando Díez Ubierna. Su existencia se resolvía en Villatoro, sobre $270 \mathrm{~m}^{2}$. Su única compañía era una criada ${ }^{65}$. El hogar de don José Iglesias, beneficiado en Villimar, era más complejo. Sobre $212 \mathrm{~m}^{2}$ de suelos útiles se repartían el espacio el citado clérigo, una hermana —encargada de los quehaceres domésticos-, su madrastra y un pastor ${ }^{66}$.

Los hogares de los beneficiados parroquiales de Burgos y de los sochantres y capellanes del número de la Catedral eran numerosos. No así sus rentas anua-

$62 \mathrm{Su}$ vivienda era una «casa pegante al convento, gratuita por ser para el fin de habitación del capellán». Los casi 4.000 reales de útil anual que conseguía reunir de ambas actividades le situaban en una magnífica situación económica. ADPB. Catastro. Memoriales, J, Libro 349, folio 418. Testamento en AHPB. PN. Legajo 7170 (1770), folios 69-70.

63 Vivienda gratuita en Santa Clara. 2.700 reales/año. ADPB. Catastro. Memoriales, A, 348, folios 46-47. Testamento en AHPB. PN. Legajo 7018 (1752), folios 477-478.

64 Calle Abades $\left(180 \mathrm{~m}^{2}\right.$ de suelos más un jardín de $\left.40 \mathrm{~m}^{2}\right) .3 .200$ reales/año. ADPB. Catastro. $M e$ moriales, F, Libro 349, folio 182. Testamento en AHPB. PN. Legajo 7011 (1745), folios 384-387.

$65 \mathrm{Su}$ alcance anual era auténticamente paupérrimo, 480 reales. No se ha encontrado testamento. ADPB. Catastro. Memoriales, F, Libro 349, folios 171-174.

$66 \mathrm{Su}$ economía adquiría un grado de bondad que al anterior no le era dado como consecuencia del curato de la parroquia y de la explotación de las tierras de su beneficio y el esquilmo de un pequeño rebaño de ovejas. ADPB. Catastro. Memoriales, J, Libro 349, folios 363-371. Sin testamento. 
les ni el tamaño del espacio dedicado a la convivencia. Descuellan por sus peculiaridades el de don Manuel de Villandiego: un ama y una criada, ambas procedentes de un pueblo cercano, se encargaban de las labores domésticas. Se repartían $130 \mathrm{~m}^{2}$ en un edificio propiedad del clérigo, sito en el barrio de Vega ${ }^{67}$. Don Bernardo Zaldivar, «compadre» del anterior en la parroquia, albergaba sobre $180 \mathrm{~m}^{2}$ a su madre, a dos sobrinos, estudiantes de gramática y primeras letras, y a una criada ${ }^{68}$. Don Tomás Trescasa personaliza al clérigo acompañado de una sobrina, dedicada en cuerpo y alma al mantenimiento de la vivienda, un reducido edificio que les mantenía bastante hacinados $\left(37 \mathrm{~m}^{2}\right)^{69}$. Entre los sochantres destaca don Blas Ferrero. $190 \mathrm{~m}^{2}$ acogían, en un edificio de la Llana de afuera, a seis personas. El clérigo estaba acompañado por una sobrina, viuda acogida para comandar lo doméstico, una criada, un criado estudiante y dos familiares de parentesco indeterminado, huérfanos y alimentados de limosna ${ }^{70}$.

Los beneficiados parroquiales presidían hogares múltiples en un $23,6 \%$ de los casos. El modelo más usual - significa un $42,3 \%$ de la totalidad- era, como lo encontramos, por ejemplo, en casa de don Antonio Ángel Frávega, hallar al clérigo en compañía de su madre, viuda, un hermano ó hermana, solteros, y una criada ${ }^{71}$. Don Andrés Arnaiz introduce una variante a considerar: albergar a su lado a ambos progenitores, ya ancianos, una hermana viuda y a una familiar de parentesco indeterminado, huérfana, dedicada a las tareas domésticas, supliendo por tanto con su presencia la contratación de criadas ${ }^{72}$.

A muy corta distancia aparecen, con un 38,5\%, los hogares múltiples por hermanamiento con la presencia de, al menos, dos núcleos de convivencia residentes en el mismo edificio. Uno de los ejemplos más significativos es el ocu-

$67 \mathrm{Su}$ alcance anual era bastante precario y reducido (730 reales). Era propietario de su vivienda. ADPB. Catastro. Memoriales, M, Libro 349, folio 470. Testamentos en AHPB. PN. Legajo 7166 (1762), folios 102-103 y Legajo 7176 (1782), folio 139.

${ }^{68}$ Calle San Cosme. Además del citado beneficio actuaba como capellán de la Congregación de la Creaçón. Con todo su alcance anual era escaso (730 reales). El alquiler de la vivienda le suponía desprenderse del 22,8\% de sus ingresos. ADPB. Catastro. Memoriales, B, Libro 348, folio 68. Testamento en AHPB. PN. Legajo 7123/1 (1773), folios 287-288.

69 Beneficiado en San Esteban, vivía en ese barrio de alquiler. El alcance anual (1.600 reales) les permitía mantenerse con cierta tranquilidad. ADPB. Catastro. Memoriales, T, Libro 349, folio 592. Testamento en AHPB. PN. Legajo 7120 (1767), folios 253-254.

70 Además de sochantre, era músico en la Catedral y capellán de una capellanía anexa a la sochantría. Con todo ello alcanzaba una posición económica confortable (cercana a los 4.000 reales/año). ADPB. Catastro. Memoriales, B, Libro 348, folio 69. Testamentos en AHPB. PN. Legajo 7064 (1749), folios 21-22 y Legajo 7116 (1759), folios 96-97.

71 Plaza Mayor. $141 \mathrm{~m}^{2}$ de suelos y poco más de 1.000 reales de útil anual. ADPB. Catastro. $M e$ moriales, A, Libro 348, folio 43. No se ha encontrado testamento.

72 Calle de los Avellanos, en unos cuartos altos de un edificio en el que cual disponía de $400 \mathrm{~m}^{2}$ para efectuar la vida cotidiana. De su empleo y del cultivo de algunas heredades obtenía un útil anual cercano a los 2.500 reales. ADPB. Catastro. Memoriales, A, Libro 349, folios 44-45. Testamento en AHPB. PN. Legajo 7055/2 (1760), folios 3-4. 
rrido en casa de don Pedro Calderón. El clérigo albergaba una hermana soltera, un cuñado y una prima, ambos solteros y huérfanos, una criada y un criado estudiante junto al matrimonio conformado por un hermano, su cónyuge y un hijo de éstos de corta edad, pareja que tenía contratada a su vez a una zinzaya o cuidadora del niño y a un amanuense, ayudante de don Juan Antonio, procurador del número. Éste último, hermano del citado clérigo, admitió en su memorial tener la «vivienda en compañía de don Pedro Calderón, su hermano, beneficiado de la parroquial de San Esteban». No fue el único testimonio en este sentido, dado que doña María Sánchez de Cos, la susodicha prima era la propietaria del edificio en que vivían. Doña María fue exquisitamente detallista al informarnos que «la bivienda prinzipal y su entresuelo y parte del patio la ocupa su primo (...) con sus hermanos y demás familia». Ella, por su parte, se adjudicó la segunda planta, donde desarrollaba su vida cotidiana en compañía de una criada, si bien, como sabemos, escaleras abajo residía el resto de la familia. El útil anual que entre todos eran capaces de obtener (aproximadamente 5.000 reales) y las dimensiones de la casa, entorno a $650 \mathrm{~m}^{2}$, permiten suponer un convivir fluido y tranquilo ${ }^{73}$.

El hogar de don Francisco Ojeda es representativo de ese 11,5\% de hogares múltiples en que corresidían dos ó tres núcleos familiares de carácter colateral bajo los mismos techos. El clérigo estaba acompañado de una criada y de dos familias más. La primera estaba compuesta por su cuñado viudo, ciego y de edad avanzada, padre de dos hijas. Una estaba soltera y ejercía labores de «ama» en la casa. La otra estaba casada con un notario apostólico. Ambos tenían un hijo y una hija en edad escolar. Ildefonso de Porras, el notario, afirmó en el memorial que redactó de su propia mano que «la manutención de la familia depende de don José de Ojeda, beneficiado de la parroquial de San Esteban, tío de la mujer». La casa que albergaba a estas siete personas tenía un entresuelo con caballeriza y «un alto con cinco quartos, un desván, una cocina y un desbán pequeño». Con todo su espacio habitable era bastante pequeño, con no más de $50 \mathrm{~m}^{2}$, tamaño exiguo que, sin duda, obligaba al hacinamiento y la incomodidad. La economía del hogar no era tampoco excesivamente generosa. El $77,5 \%$ de los ingresos los aportaba el clérigo ${ }^{74}$. Otro ejemplo es el hogar de don Juan García Tenorio Brizuela, quien vivía en compañía de una hermana, un familiar, huérfano, de parentesco desconocido, una criada y un sobrino, casado, padre de cuatro hijos y curador, a su vez, de un sobrino también huérfano. Su empleo como oficial de libros en la administración general de las Rentas Reales y las múltiples ocupaciones del clérigo les permitían disfrutar de un envidiable

${ }^{73}$ Su composición interna es la común en muchas de los edificios de Burgos, es decir, un inmueble con mucho fondo y escasa anchura. En el entresuelo hallamos un patio, oficinas para el carbón, caballeriza y trojes y dos altos más desván. ADPB. Catastro. Memoriales, P, Libro 349, folios 569-570, J, Libro 345, folio 486 y M, Libro 346, folios 290-291. No he hallado testamentos.

74 ADPB. Catastro. Memoriales, J, Libro 349, folio 377 e I, Libro 345, folio 186. Sin testamento. 
nivel de rentas, cercano a los 9.000 reales/año, si bien ello no se traduce en la ocupación de una casa con un tamaño grande - los suelos útiles para la corresidencia no llegaban a los $110 \mathrm{~m}^{2}{ }^{75}$.

El hogar de don José Gil, sochantre de día de la Catedral, es muy interesante por su estructura. El clérigo se hacía acompañar por una criada, un sobrino huérfano y otro casado. Éste, con plaza de músico en la Catedral, disfrutaba de su cónyuge y una hija de corta edad. No tuvo ningún inconveniente en afirmar que su vivienda estaba «en la casa donde reside don José (...) (y que) se sirve de las criadas del citado». Los más de $300 \mathrm{~m}^{2}$ de la casa tenían en los $75 \mathrm{~m}^{2} \mathrm{de}$ un jardín anexo un complemento ideal para el disfrute y la tranquilidad, condimentada la vida cotidiana con una más que aceptable aportación económica lograda por ambos individuos ${ }^{76}$.

En última instancia, hallamos hogares múltiples con un sesgo laboral -el 7,7\% de los hogares del TIPO 5-. El hogar de los hermanos don Mateo y don Pedro de Hojas es, a mi juicio, el más revelador. En él tenían cobijo ambos clérigos, un criado y una criada. Esta última era viuda y madre de una muchacha soltera, la cual también tenía atribuidos quehaceres domésticos. El entresuelo - con su portal, un cuarto y una caballeriza - dos viviendas altas y un soleador posibilitaban la existencia de $280 \mathrm{~m}^{2}$ de suelos habitables, muy acordes con los jugosos ingresos de ambos eclesiásticos ${ }^{77}$. En el Hospital del Rey, el hogar del comendador don Gonzalo del Río y Castro era también singular, y más si tenemos en cuenta que lo usual - el 66,7\% - era que el clérigo conviviera en exclusiva con una o dos criadas. Don Gonzalo tenía junto a sí a su madre, viuda de edad avanzada, y a tres criadas, dos de las cuales eran hermanas. Su saneada economía y el mucho suelo de su casa — casi $300 \mathrm{~m}^{2}$ — eran más que suficientes para mantener y acoger con amplitud a tales personas ${ }^{78}$. Regalar las camas de las estancias nocturnas al servicio doméstico femenino no era nada extraño puesto que en la inmensa mayoría de los hogares eran las únicas voces, además de la del clérigo, que era posible escuchar.

75 Don Juan era, además de beneficiado en San Gil, capellán en varias capellanías y congregante de la Creaçon. Vivían en la calle Hospital de Ciegos, es decir, en una de las zonas más deprimidas y pobres de Burgos. ADPB. Catastro. Memoriales, J, Libro 349, folios 350-351 y V, Libro 347, folio 537.

76 Residían en la concurrida por los clérigos burgaleses calle Abades. Entre ambos disponían de más o menos 6.000 reales al año para el mantenimiento del hogar. ADPB. Catastro. Memoriales, J, Libro 349, folio 406 y F, Libro 344, folio 855. Testamento en AHPB. PN. Legajo 7064 (1751), folios $652-655$.

77 Entre ambos obtenían casi 10.000 reales, los cuales, rebajado un $12 \%$ de los gastos habituales e imprescindibles, les dejaba aproximadamente 7.000 reales de útil anual. ADPB. Catastro. Memoriales, M, Libro 349, folio 466 y P, Libro 349, folios 567-568. Se les redactó varios testamentos entre 1747 y 1763.

78 La ración que el Hospital le tenía asignada se traduce en aproximadamente 4.300 reales/año. ADPB. Catastro. Memoriales, G, Libro 349, folio 658. 


\section{3. «... UNA CAMA COMPLETA». EL SERVICIO DOMÉSTICO EN LAS ÚLTIMAS VOLUNTADES DEL CLERO BURGALÉS}

No es un hecho atribuible en exclusiva a los clérigos — cuadro III- Lo encontramos también en las últimas disposiciones de otros segmentos de población que tenía contratado personal doméstico. Se ordena pagar los salarios atrasados - por toda una vida de quehaceres y laboriosidad-. Se señalaba también en ocasiones una sustanciosa gratificación por el buen hacer de las criadas y criados en la gestión de los asuntos de la casa, de las enfermedades, etcétera. Y se les premiaba igualmente, aunque no siempre, con la entrega de una cama completa ${ }^{79}$.

\begin{tabular}{|c|c|c|c|c|c|c|c|c|c|c|}
\hline \multirow{3}{*}{ CUADROIII } & \multicolumn{10}{|c|}{ PRESENCIA DEL SERVICIO DOMESTICO EN LOS TESTAMENTOS BURGALESES (S.XVIII) } \\
\hline & \multirow{2}{*}{$\begin{array}{l}\text { Mención } \\
\text { criadas }\end{array}$} & \multicolumn{3}{|c|}{ Entrega de mandas $(\%)$} & \multicolumn{6}{|c|}{ Designacion de herederos unversales $(\%)$} \\
\hline & & Cama & Enseres & Dinero & Hijos & Conyuge & Familiares & Criados & Amo & Otros \\
\hline No cualificados (1) & 0 & 0 & 0 & 0 & 50 & 0 & 50 & 0 & 0 & 0 \\
\hline Criados y sinientes & 0 & 0 & 0 & 0 & 14.6 & 14.6 & 28.6 & 0 & 42.8 & 0 \\
\hline Labradores & 3.5 & 50 & 100 & 50 & 71.9 & 17.5 & 8.8 & 0 & 0 & 1.8 \\
\hline Maestros artesanos & 5.9 & 40 & 0 & 20 & 77.8 & 9.5 & 7.7 & 0 & 0 & 4.4 \\
\hline Oficiales artesanos & .0 & 0 & 0 & 0 & 45.5 & 54.5 & 0 & 0 & 0 & 0 \\
\hline Comerciantes & 13.6 & 66.6 & 0 & 0 & 63.6 & 22.7 & 4.5 & 0 & 0 & 9.2 \\
\hline Burócratas & 10.9 & 60 & 60 & 40 & 76.1 & 8.6 & 6.6 & 0 & 0 & 8.7 \\
\hline Servicio público & 8.2 & 83.3 & 0 & 33.3 & 70.9 & 15.2 & 4.8 & 0 & 0 & 8.7 \\
\hline Nobleza rentista & 4.5 & 0 & 0 & 0 & 86.4 & 13.6 & 0 & 0 & 0 & 0 \\
\hline Clero & 48.1 & 77.6 & 57.1 & 65.3 & 0.8 & 0 & 65.6 & 5.6 & 0 & 28 \\
\hline Miltares & 13.8 & 25 & 0 & 50 & 44.8 & 3.4 & 17.2 & 6.8 & 0 & 27.5 \\
\hline & & & & & & & & & ladoracic & $n$ propia \\
\hline
\end{tabular}

79 «La cama en que duerme» es la clave sistemáticamente, tal y como lo dejó dicho, por ejemplo, don Antonio de la Peña, beneficiado en Nuestra Señora de Viejarrúa. ADPB. Catastro. Memoriales, A, Libro 348, folios 18-19 y AHPB. PN. Legajo 7081 (1751), folios 435-436 y Legajo 7117/2 (1762), folios 5-6. El pago de los salarios atrasados, la gratificación económica, la entrega de la cama y de otros enseres era una honesta misio que les permitiría acceder a un nuevo estado, o al menos aspirar a él en buenas condiciones. En algunos casos, como en el testamento del citado don Antonio, se quiere incluso asegurar que no caigan en el total desamparo: «encargo que el primer año de mi fallecimiento se la dexe vibir y avittar en mi casilla pequeña sin llevarla rentta alguna».

Hispania Sacra, LVIII

118, julio-diciembre 2006, 545-577, ISSN: 0018-215-X 
El gráfico II lo patentizan de manera evidente. El clero burgalés mencionó de manera explícita al servicio doméstico que tenía contratado en casi la mitad de las últimas voluntades recopiladas. Y lo hacía para entregarles, con un porcentaje que no nos puede dejar indiferentes, en el $80 \%$ de los casos, una cama completa a sus criadas y/o amas. A los criados se les daba únicamente «vesti$d o s »^{80}$. Además del lecho nocturno se les hacía «manda» de enseres de la casa en la mitad de los testamentos y de dinero en una mayoría cualificada de las ocasiones $-65 \%$ de los documentos-. Con excepción de los mercaderes, de los militares (oficiales) y de los burócratas, - y con unos porcentajes tampoco excesivamente abultados-, en las demás categorías profesionales apenas se acuerdan de sus criadas, amas ó criados, aunque, eso sí, cuando se les menciona también se les otorga una cama completa en muchas de las ocasiones.

¿Era esa cama completa, ubicada en la estancia ocupada por la criada ó el ama, un inocente conjunto de menajes para descansar durante la noche ó su aparejo había conocido una impronunciable etapa de calor humano desenfrenado? ¿Por qué razones se le hacía entrega a la criada de tal conjunto de enseres? En unas pocas ocasiones las sobrinas también eran agraciadas con la entrega de una cama completa. Lo común es que fueran acreedoras de otras propiedades más jugosas y caras, como rentas, joyas o muebles de distinto tipo. A las criadas, de manera sistemática $(77,8 \%)$, la cama en que dormían, dinero y enseres de la casa.

80 El 85,7\% de los 119 clérigos para quienes hemos recopilado algún testamento (que suponen el $62,6 \%$ de los eclesiásticos de la ciudad) tenía personal contratado y, sin embargo, sólo en un $48 \%$ citó de forma expresa a los criados en sus últimas voluntades. La entrega de los salarios la ordenan el $96 \%$ de los clérigos, la cama completa en el 77,6\%, gratificaciones económicas complementarias el 65,3\% y enseres y pertrechos de la casa en el 57,1\%. Véase R. LóPEZ LóPEZ: «Aproximación al clero urbano ovetense», Cuadernos de Investigación Histórica, 11 (1989), Madrid, pp. 120. Son varios los ejemplos que patentizan que al criado se le entregarán «de mis vestidos calzón, chupa, casaca y capa», «de mediana calidad», mientras que al ama ó a la criada, además de ropas de luto «de la mejor calidad», se le destina la cama completa. AHPB. PN. Legajo 7026 (1761), folios 245-248 (Don Manuel de Salamanca, beneficiado parroquial) ó AHPB. PN. Legajo 7087 (1748), folios 212-217 (Don Alonso Calderón de la Barca, deán de la Catedral). Don Juan de Escalada, canónigo, «comunicó que en consideración a la fidelidad y cuidado con que le havía asistido por tiempo y espacio de más de Veinte y siete años (...) se le diesen (a la criada) dos Camas de ropa para su uso (...) (y a) su criado todos los vestidos que hubiesen Servido para el adorno de su Cuerpo». AHPB. PN. Legajo 7094 (1761), s/f. 


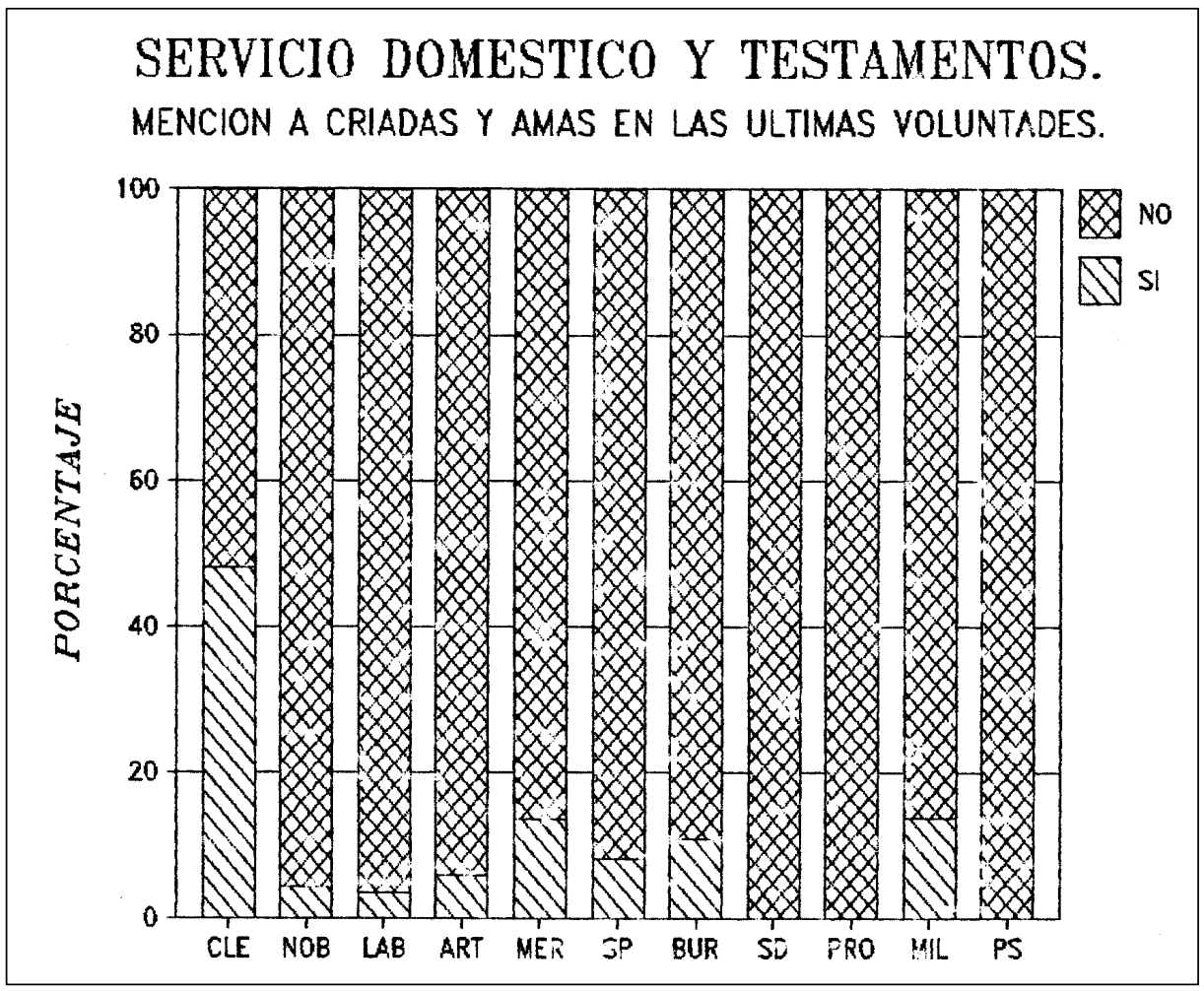

CLE $=$ Clérigos $\mathrm{NOB}=$ Nobleza rentista $\mathrm{LAB}=$ Labradores $\mathrm{ART}=\mathrm{Maestros}$ artesanos $\mathrm{MER}=$ Mercaderes $\mathrm{SP}=$ Servicio público

$\mathrm{BUR}=$ Burócratas $\mathrm{SD}=$ Servicio doméstico $\mathrm{PRO}=$ Oficiales artesanos (proletariado) $\mathrm{MIL}=\mathrm{Militares}$ $\mathrm{PS}=$ Pobres solemnidad

Los testamentos de los eclesiásticos y de los militares son los únicos en que aparecen las amas ó criadas como herederas. En las restantes categorías profesionales, en ningún caso. Los criados, sin embargo, confiaban en un $42,8 \%$ en sus patronos como destinatarios de los cortos patrimonios que quedaban a la hora de la muerte. Una realidad más asimétrica es difícil de encontrar. De los 125 testamentos de clérigos recopilados, en siete ocasiones, es decir, en el 5,6\% de las ocasiones, el testador apuntó directamente al ama ó a la criada que le servía como heredera universal de sus pertrechos. Los hermanos $(32,8 \%)$ y los so- 
brinos $(24,8 \%)$ eran respectivamente los más directamente favorecidos por el clero. Entre los militares, el servicio doméstico fue señalado como heredero en el $6,8 \%$ de los testamentos.

En el testamento de don Juan Antonio Udías se dice expresamente «mando a María Gutiérrez mi Prima que a estado, y se alla, en mi asistenzia, en attenzión a el vuen servizio que me a hecho y la de haver asistido y servido en la misma forma a la expresada mi Madre, una Cama de ropa compuesta de colchón, gergón, dos sávanas, dos lenzuelos, dos mantas, dos colchas, una de Ivierno y otra de verano, y quatro almuadas, y además, quatro servilletas, dos manteles, dos paños de manos y un Candelero, y una palmatoria de bronze y una pañada de lienzo de diez baras, y que se le paguen los salarios que se le estén deviendo; y además encargo a dho don Balentín de Udías, mi sobrino, Cuide de ellas, y las asista y mire con Caridad durante los días de su vida en attenzión a el buen servizio y asistenzia que dejo referida ${ }^{81}$. Este denso párrafo resume de manera concluyente los asertos que se desean matizar en este artículo. Asilar familiares (sobrinas, primas, hermanas...) posibilitaba en ocasiones eliminar la contratación de amas ó de criadas, aunque no siempre era así.

A los sirvientes se le dispensó, en general, por parte del clero un trato muy correcto. Lo demuestra, por ejemplo, el testamento de don Benito de Herrán: «(A) mi Criada (...) por la buena ley, asistenzia y fedelidad, verdad y Justificazión con que me ha servido y sirve la mando por Una Vez Ciento Cinquenta Rs Vn y una Cuja de pino encordelada, dos Colchones, dos mantas, dos savanas de Lienzo, dos Lenzuelos, una Colcha Blanca ó encarnada y quatro almoadas de Lienzo» ${ }^{82}$. En muchas ocasiones se trataban los clérigos mejor al personal doméstico que algunos esposos a sus cónyuges ${ }^{83}$. Don Blas de Illana, no en su testamento cuanto en una «Memoria» adjunta de singular contenido sociológico, patentizó su cariño afirmando que «a mi Criada actual sesenta ducados en atenzión a su buen servizio y al Cuidado que tiene y espero que en adelante tendrá de las Cosas de mi casa, y así mismo la mando la Cama en que al presente duerme que está en la Sala que mira a la plaza (Mayor), que se ha de componer de la Armadura que es de buena madera, con la cavezera labrada y algunas piezas doradas, gergón, tres colchones, tres mantas, quatro sabanas y quatro almoadas, dos que tiene y las otras dos para que pueda mudar, un Cobertor y una colcha blanca para Verano». Los herederos universales de sus bienes no

81 AHPB. PN. Legajo 7170/1 (1770), folios 69-70.

82 A una sobrina le dejó «el usufructo y renta de toda la hazienda raíz (24 fanegas de pan por mitad)» y a otra, monja en un convento de la ciudad, «por una Vez quatro savanas y quatro Almohadas de Lienzo nuevas y dos Colchones, los mejores que tengo y dos mantas, la Una nueva». Ibidem, Legajo 7011 (1745), folios 384-387.

${ }^{83}$ Algunos ejemplos en F. SANZ DE LA Higuera: «A la sombra de la muerte: Viudez espléndida, viudedad paupérrima. Burgos a mediados del Setecientos», Cuadernos de Investigación Histórica, 22 (2005), Madrid, pp. 431-461. 
serían sus parientes, que al parecer le maltrataron y le dejaron abandonado en las horas de infortunio, sino sus «compadres» de trabajo, los beneficiados de la parroquia en que ejercía sus quehaceres eclesiásticos, sus mejores amigos, a la postre ${ }^{84}$.

Algunos testamentos destilan algo más que cariño y agradecimiento por el personal doméstico. Ello se trasluce, a mi juicio, de las declaraciones de don Felipe del Hoyo Santamaría en el devenir de su agonía y postreras decisiones. Convirtió a «Doña Jpha de Tapia, que se alla en mi Compañía» en protagonista estelar de sus últimas voluntades. Entre otras muchos enseres mandó a la «que se alla en mi Compañía asistiéndome con ttodo afectto y cariño Onze mill rrs Vellón por una Vez Comprendiéndose en ellos y por pagados los salarios que la he devido Conttribuir de Veintte y ocho años que a que esttá en mi Compañía (...) esttando en mi Cassa al Respectto de Veintte ducados cada año». Se añade finalmente que era su deseo «no se la rejisttre Cofres ni Arcón alguno que ttubiere ni se la pida quentta de Nada sino de la que quisiera dar por la mucha Satisfazion y Comfianza que ttengo de la suso dha Xpstiandad y Realidad que profesa; y ttodo lo referido se la dé estté o no en mi Casa y Compañía al tiempo de mi fallezimiento». En el IPM de don Felipe se especifican de una manera puntual y extrañamente inusual — de hecho es el único de los recopilados en que sucede tal circunstancia- los «Trastos del Quarto que havitava $D .{ }^{a}$ Jpha de Tapia». Comienza la descripción con la mención, sin mediar más palabras, de «Un Catre de haya dado de encarnado» ${ }^{85}$.

84 Don Blas sufría de «acçidente de melancolía morvo», razón por la que decidió pasarse «a vivir en casa deel referido mi Pariente (...) contemplando me serviría de alivio la Comunicación frequente con dho mi pariente y Su familia». «... en todo el tiempo que Viví y havite en casa de el referido (...) fui servido y asistido por mis Criadas, a quienes pagué sus salarios y gastos como también los míos de comida y bebida, y todos los demás gastos ordinarios como luz, labandera, medicinas y demás cosas necesarias». La queja más grave que de ese período se derivó es que «no ocupé Cuarto determinado reservado para mí, porque, aunque el año primero y no entero, dormí en la Sala, para todo lo demás era común para todos, y lo demás de el tiempo dormí en Sitio que no es de estimación —a pesar de correr de su cuenta en los dos años «la mitad de el carvón que se gastó»-. Finalmente se volvió a su propia casa y los familiares fueron apartados de sus bienes. AHPB. PN. Legajo 7152/2 (1752), folios 18-19.

85 Doña Josefa fue una de sus testamentarias pero no su heredera universal de forma explícita. Ello hubiera despertado, con bastante probabilidad, los más ruidosos comentarios, quizás murmuraciones. El caudal de pertrechos que le mandó en el testamento — a lo ya dicho se añade «la mitad de la ropa blanca, un cattre y seis colchones de los mejores, seis mantas de las que quisiere escoger, Todos los quadros que tiene y adornan su quarto (...) lo que necesitase de Cocina para su Uso y habitación y que quisiere elegir como ttambién todas las esteras y felpudos que tuviere la Casa, dos Cujas con sus pajeros (...) Una dozena de platos de pelttre y todo el Bridrio y vidriado que quedase, Y la mitad de todo el alimento Comestible y chocolate que dejare...». AHPB. PN. Legajo 7081 (1750), folios 182-185. ¿Es una mera casualidad que se significara de una manera detallada el contenido del cuarto de la criada ó es que el notario tradujo el imaginario social, la murmuración ó la acusación popular a través del recorrido por las estancias de la casa del arcediano? ¿Fueron 28 años de absoluta distancia ó hubo algo más?

Hispania Sacra, LVIII

118, julio-diciembre 2006, 545-577, ISSN: 0018-215-X 
Un excelente ejemplo del trato diferencial que se daba al personal doméstico lo encontramos en el testamento de don Alonso Carrillo y Acuña. Al ama y a la criada se les pagan los salarios atrasados, se les asigna una substanciosa cantidad «en attenzión a su lealtad y buen Servizio que me ha hecho» y se les hacía entrega de una cama completa así como de otros ajuares y menajes de casa para que «pueda ponerse en su Cuartto». Su criado masculino, un paje, «por el Buen servicio que me a hecho en el espazio de más de seis años todos los Vestidos interiores y exteriores de mi uso (...) a excepzion de los nuebos» ${ }^{86}$. Don Gabriel Brizuela aparece en el extremo contrario, por el número de los testamentos redactados y por la cantidad de los criados a su servicio. Era un clérigo, beneficiado parroquial, en nada cercano al personal doméstico. Los $244 \mathrm{~m}^{2}$ de su vivienda - que lo era en propiedad - se repartían entre el clérigo, dos criadas y un criado mayor. No se acuerda de ellos en absoluto, en ninguna de sus últimas voluntades. Su alma es, sin embargo, reiterada y obsesivamente mencionada como beneficiaria de sus mandas ${ }^{87}$.

\section{TRES EJEMPLOS — ¿MODELOS? - DE RELACIONES ÍNTIMAS ENTRE ECLESIÁSTICOS Y MUJERES EN EL BURGOS DEL XVIIII}

La prueba más consistente sobre la excepcionalidad de las situaciones atípicas y reprobables entre el clero burgalés es el escaso número de documentos que prueban su existencia. Empero, cuando aparecen, socavan la credibilidad del colectivo, aunque no sean más que la excepción que confirma la regla. Sin duda el más espeluznante de los tres documentos que se han recopilado en los archivos burgaleses es el que nos llega a través de la misiva que don José Manuel Ortíz Taranco ${ }^{88}$ envía al Arzobispo en julio de 1765. Para evitar excesivas disgresiones, haré mención literal del documento. Después será examinado el contexto en toda su trascendencia:

\footnotetext{
${ }^{86}$ ADPB. Catastro. Memoriales, A, Libro 348, folio 31 HPB. PN. Legajo 7213 (1778), folios 378-37.

87 ADPB. Catastro. Memoriales, G, Libro 349, folios 198-201. AHPB. PN. Legajo 7000 (1730), folios 271-272, Legajo 7009 (1742), folios 321-322, Legajo 7019 (1754), folios 128-129, Legajo 7104 (1756), folio 521 y Legajo 7105/2 (1757), folios 321-322. Lamentablemente es este caso no disponemos de la «memoria firmada de mi Puño en que (...) ago algunos legados y mandas y otras cosas correspondienttes al Descargo de mi Conciencia», en la cual quizás se dictara lo relativo a los criados.

88 Prior (dignidad) y racionero en 1751 — canónigo en 1770 -, residía entre viudas paupérrimas en Vega, extramuros, aunque sus ingresos, y los del capellán del número que le acompañaba, eran muy suculentos, por encima de los 8.000 reales/año. Las dos plantas que él, su «familiar»—un capellán del número- una criada y un criado estudiante, ocupaban les proporcionaban $1.400 \mathrm{~m}^{2}$ de suelos habitables. En el «entresuelo» aparecen dos mujeres viudas, de extracción noble, dedicadas a la rueca y a la mendicidad. ADPB. Catastro. Memoriales, M, Libro 349, folios 454-455, J, Libro 349, folio 396 y M, Libro 346, folio 44.El testamento de don Manuel en AHPB. PN. Legajo 7150 (1770), folios 373-376.
} 
«Muy Sr. Mío. Días hace que se me dio aviso de que Dn Balentín Calbo tenía embarazada a la Criada de su Casa, y que se desembarazó el día de Sn Antonio en casa de D. ${ }^{a}$ Ana Romero. No sólo no quise proceder por que no me toca, sino encargué mucho el Secreto, por respeto a nuestro Estado. Después se me ha dicho que la cosa es pública en el pueblo, y que se murmura con mucha libertad, que nada hagan con el dicho Dn Balentín, ni el Arzobispo, por que no está sugeto a su Jurisdiszión, ni sus Jueces, por que se han empeñado en disimular. Participolo a Vmd, cumpliendo con mi conciencia, suplicándole que para su gobierno, y el mío, tenga presente el día en que le hago este recuerdo. Burgos y 6 de julio de $1765{ }^{89}$.

En contados casos tan escasas y apretadas líneas han encerrado tan densos y controvertidos asuntos. El feo evento no dejó títere con cabeza. Implicaba de una manera directa a personas y colectivos de toda la pirámide estamental burgalesa. Embarazo, desembarazo, murmuraciones populares, pacto de silencio, cortina de humo... una secuencia sin duda abominable. En ocasiones, se acusaba a los clérigos de mantener relaciones con sus criadas, e incluso de la existencia de hijos ilegítimos. En el caso de Valentín Calvo no cabe ninguna duda. La tentación, en forma de viuda, criada, sobrina, etc., estaba muy cercana: bajo los mismos techos que los eclesiásticos.

El segundo asunto esta relacionado con las andanzas del canónigo Sota. El Cabildo se ve obligado, por su contumacia e irresponsabilidad, a llamarle la atención, «amonestándole (y conminándole a que) se abstuviese de tratar con la primera Dama y demás farsantes de que se compone la farsa que reside en esta Ziudad (...) (por) el escándalo y nota que causaba y avía causado (...) con semejante conbersazión y trato». El affaire venía de largo, dado que ya se le había advertido en otras ocasiones sobre que «se abstuviese de comunicar assí de día como de noche con la primera Dama y demás farsantes de que se compone la Comitiva y farsa que está en esta Ziudad, y de no concurrir directa ni indirectamente a Cassa alguna, a donde la expresada estuviesse» ${ }^{90}$.

El análisis de las circunstancias vitales de ambos clérigos, don Valentín Calvo, beneficiado en la parroquia San Martín, y don Gregorio Sota, canónigo de órdenes menores en la Catedral, nos ofrece un contrapunto sobre sus comportamientos.

$\mathrm{Al}$ fallecer (1795) se le efectúa al primero un inventario post-mortem cuyo caudal, unos raquíticos 1.762 reales, quedaba más que ensombrecido por los 2.000 de que era deudor. Como era tradicional entre los beneficiados de esa parroquia, su casa estaba situaba en las cercanías de la iglesia, entre el periférico

89 ACCB. Volumen 55, P2, folio 128.

90 ACCB. Actas capitulares. Libro 106. Cabildo de 17 de agosto de 1750, folio 167-168. ¿La osadía del canónigo — «el escándalo y nota que causaba y avía causado con semejante conversación y trato»— enervaba a sus compadres por el delito en sí mismo ó por las envidias no declaradas que el asunto desataba en el seno del Cabildo?

Hispania Sacra, LVIII

118, julio-diciembre 2006, 545-577, ISSN: 0018-215-X 
barrio de San Pedro de la Fuente y el Arco de Fernán González. El IPM de don Valentín ofrece, de entre los 47 post-mortem recopilados para el estamento eclesial, el caudal más reducido. En su testamento, nombró «por Única y unibersal heredera a (...) Ángela López, mi ama por justas Causas que a ello me mueben y buen servizio que me haze y espero que continue en él». La «Quenta de lo que yo Ángela López traje a Casa de mi amo Dn Valentín Calbo»-se anotan «dos pajeros, uno que está en la Cama de mi Amo y otro en la mía» y «un Tapíz grande que está en la Cama del Amo»—- refleja el inicio de su peculiar relación. Desde 1768, «una grave y dilatada enfermedad» le apartó de «Casa y Compañía de sus Padres» y le hizo trasladarse a la vivienda de un escribano del Real Adelantamiento, don José Zaldivar, quien le «alimentó, cuidó y asistió por medio de sus Domésticos, costeando los precisos y Crecidos gastos que ocasionó en el dilatado tiempo que así le mantubo».

Don Valentín volvió, sanado de sus patologías, a «la Compañía de sus Padres (...) y nunca pudo lograr la Cobranza». Después don Valentín tomó casa aparte y el citado se la equipó, «dándole las Ropas, muebles y efectos correspondientes». Ello generó unas crecidas deudas, «dos mil reales (...) del ymporte de Alimentos y gastos», a lo que se añaden «todos los Vienes y Ajuares que había en su Casa». Finalmente, fallecido el clérigo, el ama se vio obligada a llegar a un pacto con el citado Zaldivar, «por la cortedad de los Caudales (...) y con el deseo de ebitar que estos se consuman en los considerables gastos de la substentación de un pleito dilatado». Convinieron que se le entregaran 300 reales como fórmula para que desistiera de tomar nada que proviniera del hipotecado caudal del difunto clérigo. Los 2.000 reales saldrían del «Beneficio que tengo ganado en dha Iglesia de Sn Martín» ${ }^{91}$.

Don Gregorio Sota residía en la plazuela de Santamaría, a la vera de la Catedral, templo en el que ejercía su empleo de canónigo. Obtenía anualmente una cantidad cercana a los 9.000 reales de ingresos. Una casa, propiedad del susodicho Cabildo, albergaba, sobre aproximadamente $400 \mathrm{~m}^{2}$ de suelos habitables, al clérigo, a una criada y a un criado - un típico hogar sin estructura familiar, característico de los eclesiásticos medio-altos de la ciudad-. Lamentablemente no disponemos de su IPM. La media de los post-mortem hallados para los canónigos se sitúa en los 65.000 reales. No era pobre ni parece que bajo sus techos ocurrieran turbios asuntos, como sucedía en casa de don Valentín. El trato con criadas era propio de clérigos paupérrimos. Él era miembro de la élite eclesial y sus devaneos los ejercitaba en otros pagos más selectos ${ }^{92}$.

91 Llama la atención, en primera instancia, las similitudes entre las peripecias de don Valentín y del anteriormente citado don Blas de Illana. ¿La enfermedad del clérigo fue un vórtice que aproximó hombre, clérigo, y mujer, sirviente, hasta el interior del lecho? AHPB. PN. Legajo 7205 (1795), folios 516-532.

92 ADPB. Catastro. Memoriales, G, Libro 347, folio 197. AHPB. PN. Legajo 7218 (1783), folios 
A medio camino entre el aborto en que se vio implicado don Valentín y los ajetreos de don Gregorio con las mujeres de la farsa se encuentra la preñez de Don Francisco de Agustina Cariga. El documento rubricado el 13 de agosto de 1731 lo certificaba con rotundidad. Como consecuencia de «Ziertos actos de Continenzia» con Josefa Pérez de Bustillo, natural del lugar de Carasa, localidad en la que el clérigo ejercía como beneficiado. «Allandose donzella y tenida por tal (...) se hizo preñada y lo quedó al tiempo que el otorgante (el clérigo) salió de dho lugar». Josefa sería madre de una «Criatura que Dios nro señor fuere servido de sacar a luz». El eclesiástico la reconocía como suya y se obligaba desde «cumplidos que sean los dos años y medio de su hedad desde que nazca (...) tiene obligazión a Criarla y mantenerla según lo que está Capitulado por escriptura». Don Francisco, haciendo un encomiable ejercicio de responsabilidad histórica, se comprometía «a mantener, Criar Y educar a dha Criatura, y darla el estado que Dios nuestro Señor la ynspirare como Padre lexitimo que Confiesa ser de ella» ${ }^{93}$.

\section{A MODO DE CONCLUSIÓN}

Entre las filas del clero de mediados del XVIII se detecta la presencia de individuos que sucumbieron, entre otros, a los pecados de la carne. En general, los eclesiásticos eran modélicos y estrictos cumplidores de sus deberes. Sin embargo, alguno se descarrió y sus conductas irregulares delataron que eran personas de carne y hueso con medios suficientes para vivir pero con escasa o nula vocación. La apetencia y el disfrute sexual entre los eclesiásticos en la Edad Moderna ¿estaban directamente ligados con su nivel de rentas y de fortuna? Los tres ejemplos aquí pergeñados apuntan a que la respuesta a esta interrogante debe ser negativa, al menos para la globalidad de los clérigos. Los tres eclesiásticos eran representantes de tres maneras de vivir, de tres tipos de vida - de canónigo, de beneficiado de pueblo y de proletario clerical urbano-, tremendamente distanciados por sus ingresos e idiosincrasias personales ${ }^{94} \cdot$ ¿Era fruto

220-221. Que se sepa con certeza él era la oveja negra del Cabildo, amante, además, del «Juego de esgrima (...) propio de seculares y ajeno a eclesiásticos» y de salir de casa «de corto con zapato blanco». Contravenía la Constituciones Sinodales en múltiples ocasiones.

93 AHPB. PN. Legajo 7001 (1731), folio 459. ¿Josefa y el clérigo habitaron bajo los mismos techos y con la tentación siempre cercana? El fruto de su acoplamiento fue un recordatorio permanente de un amancebamiento de incalculables consecuencias. Acosado por las circunstancias no pudo esperar a la redacción de un testamento para sincerarse con la historia. El profesor BRAVO LOZANO nos muestra otras estrategias, más dilatorias, y más culpables, en Familia busca vivienda..., Madrid, 1992, pp. 104105. Con todo, nada que ver con otras prácticas analizadas por F. NúÑEZ RoLDÁN: El pecado nefando del obispo de Salamina. Un hombre sin concierto en la Corte de Felipe II, Sevilla, 2002.

${ }_{94}$ ¿Estas conductas irregulares fueron propias exclusivamente de individuos con nula o escasa vocación para la vida eclesiástica, incardinados entre el clero por razones meramente económicas?

Hispania Sacra, LVIII

118, julio-diciembre 2006, 545-577, ISSN: 0018-215-X 
sólo de la soledad y de la tentación cercana? Cada uno encontró el placer en escenarios completamente diferentes. Aparecen situaciones muy íntimas y otras más bulliciosas. Las patologías físicas, o psíquicas, pueden ser una de las causas explicativas. ¿Se le debe reprochar a la mujer - fuera criada, ama, actriz ó parroquiana - la responsabilidad de lo ocurrido? A mi entender compartieron autoría e implicaciones, si bien el clérigo estaba obligado, por su estatus, votos y edad a refrenar al máximo la satisfacción de sus apetencias y necesidades. Empero, el calor humano siempre ha derrotado las imposiciones más absurdas de la humanidad. ¿Existía indefensión en las criadas? ¿Estaban sometidas a la violencia doméstica en un caldo de cultivo ideal para la trasgresión? Es bastante probable que la respuesta a esos interrogantes sea otro rotundo no, aunque no se descarte el abuso como un escenario posible. 